\title{
Service User Involvement in the Evaluation of Psycho- Social Intervention for Self-Harm: A Systematic Literature Review.
}

\author{
James Ward' ${ }^{1}$, BSc (Hons), PG Dip \\ Claire DeMotte BSc (Hons), MSc
}

Di Bailey BSc (Hons), MSc, CQSW, ASW, Dip Inn Mental Health

${ }^{1}$ Address for correspondence:

James Ward, 47 Finchale Avenue, Brasside, Durham, DH1 5SD Tel: 01913764271 


\section{Abstract}

\section{Background:}

The efficacy of interventions and treatments for self-harm is well researched. Previous reviews of the literature have highlighted the lack of definitively effective interventions for self-harm and have highlighted the need for future research. These recommendations are also reflected in clinical guidelines published by the National Institute for Health and Clinical Excellence (NICE, 2004) which also call for service user involvement in studies of treatment efficacy.

\section{Aims:}

A systematic review was undertaken to determine i) what contributions service users have made to the evaluation of psychosocial interventions ii) by what methods have service users been involved iii) in what ways could service user involvement supplement empirical evidence for interventions.

\section{Methodology:}

Electronic searches were completed on the $28^{\text {th }}$ January 2011 of the Medline (1950-present), Web of Science (1898-Present) and Psychinfo (1979-present) databases using 13 separate search terms. References were independently sifted according to set criteria by two of the authors to ensure inter-rater reliability.

\section{Results:}

65 references were included in the review. $59 \%$ of studies were empirically based, $26 \%$ used qualitative data collection methods to gather service user narratives. Only $8 \%$ of studies used a mixed-methodology to combined qualitative and quantitative data collection.

\section{Conclusion:}

Service user involvement is a rarity in the evaluation of psycho-social interventions despite its use being mandated by the NICE and evidenced as effective in other areas of mental health (Leader, 1998). The authors make a number of recommendations for future involvement in self-harm research. 


\section{Declaration of Interest:}

None.

\section{Introduction}

Self-harm is well researched area. This reflects the prevalence of the 'risk' behaviour which is estimated to range between $4 \%$ and $6 \%$ in the general population (Brier \& Gill, 2003, Meltzer et al., 2002b) to $17 \%$ in university students (Whitlock et al, 2006) 21\% in the adult psychiatric population (Nock \& Prinstein, 2004) and 27\% in the female prison estate (Ministry of Justice, 2008). Self-harm has been linked with a significantly increased risk of completed suicide (Appleby et al., 1999; Royal College of Psychiatry, 2003) especially amongst women who self-harm repeatedly (Zahl \& Hawton, 2004). Research has focused on identifying the underlying causes of self-harm, acknowledging that the behaviour is often a method of communication (Pembroke, 1994) or an attempt to manage often overwhelming emotions (Klonsky, 2007). Increasingly the self-harm literature draws a link between the behaviour and the previous experiences of trauma (Ringell \& Brandell, 2011; Tantum \& Hubband, 2009; Simpson 2004) and/or experiencing personality 'difficulties' (Crowe \& Bunclark, 2000).

Despite the wealth of research, the prevalence of the behaviour and the public health impetus to improve outcomes for those who self-harm an evidence base for effective interventions for self-harm remains elusive. In a metaanalysis of psychosocial and pharmacological treatments Hawton et al., (1999) concluded that "more evidence is required to indicate what the most effective care is for this large patient population" (p.2). The main reason cited for the lack of evidence was small sample sizes resulting in a lack of statistical power. The dearth of evidence for effective interventions has been reinforced by the existing clinical guidelines for the management of self-harm. The National Institute for Health and Clinical Excellence (NICE) routinely grades its recommendations according to a "hierarchy of evidence" (p. 44, NICE, 2004). Recommendations are graded A-C or as a Good Practice Point, those 
receiving an 'A' grade include at least one randomised control trial ( $R C T)$ as a part of an overall body of literature which indicates a treatment effect. Those achieving a 'B' grade demonstrate a similar body of evidence but is lacking the inclusion of an RCT. Of the institutes five recommendations for psychological, psychosocial or pharmacological interventions for the short term management of self-harm none achieve a 'Grade A' or 'B' rating. Three recommendations were graded as ' $\mathrm{C}$ ' indicating evidence was based upon clinical experience from respected authorities ${ }^{2}$. The other two recommendations were classified as 'Good Practice Points' based upon the clinical experience of the Guideline Development Group. This has lead to recommendations for more RCTs to assess the effectiveness of intensive interventions ${ }^{3}$ combined with assertive outreach and group therapy for people who self-harm. Despite the NICE recommendations being made in 2004 , six years later the Royal College of Psychiatrists remained unconvinced of the efficacy of treatment approaches

\begin{abstract}
"Although an empathic approach is essential in dealing with people who self-harm, it is not clear that any one form of treatment is particularly effective, and in some cases, the most pressing need is to address the underlying social issues" (RCP, 2010, p.37)
\end{abstract}

Whilst promising interventions are commonly reported (Prinstein, 2008), often including treatments such as problem solving therapy (Hawton \& Kirk, 1989a), cognitive-behavioural approaches (Spirito \& Esposito-Smythers, 2006) and Dialectical Behavioural Therapy (DBT) for those diagnosed with borderline personality disorder (Linehan et al., 1991). However as highlighted by the $\mathrm{RCP}$ report these are not held to be consistently 'effective'. This maybe, as Hawton reports, a product of inadequate sample sizes or poor experimental design. Given the complexity and the different psychological functions that self-harm can serve (Prinstein, 2008) the authors suggest that the phenomenon can not be properly understood, nor effective outcomes of interventions measured, through empiricism alone. This is clearly

\footnotetext{
2 The NICE does not define what constitutes a respected authority.

3 The NICE does not define what it considers to be an intensive intervention.
} 
demonstrated by the assessment of treatment success being based upon the client's cessation from self-harm. The literature testifies that those who selfharm often describe their behaviour as a survival technique (Cresswell, 2006) and although the individual may have long-term ambitions to find alternative strategies to manage their emotional distress the use of self-harm is considered vitally important for coping in the present. Treatment outcomes that focus solely upon the cessation of self-harm may therefore be colluding with unrealistic expectations of the intervention or of the client in treatment (Kelly et al., 2008). This is particularly likely to be the case where self-harm is symptomatic of underlying trauma (Tantam and Huband, 2009). If cessation is an unrealistic treatment target then more personally relevant evaluations of treatment effect should be considered in efficacy research. These may include factors such as a perceived reduction in the severity of self-harm incidents, or an increased control over the behaviour. Service user satisfaction of interventions and perceptions of whether overall quality of life has been impacted upon by psychosocial treatments should also be considered in efficacy research (Kapur, 2005). These would also give insight into whether interventions adequately address the underlying social issues surrounding self-harm as highlighted by the RCP (ibid). To capture such personal experiences the authors advocate the use of narrative analysis (Roberts, 2002) or mixed methods in order to enhance the depth and validity of research evaluating self-harm interventions (Hanson, 2008).

The NICE guidelines also call for qualitative methods to be employed, most significantly for service user led research into the benefits and adverse consequences of services received. Service user led research is described as the democratization of research (Hickey \& Kipping, 1998) through which power is redistributed to those who access the services in question. This equates to the research process, usually involving the investigation of services, being incepted and controlled by those who access the service in question. Such approaches are established within government policy (Smith \& Bailey, 2010) and are reflected in the field of mental health research (Faulkner \& Thomas, 2002). These approaches could also conceivably involve existing, active service user led organisations such as the National 
Self-Harm Minimisation Group. To date however the recommendation for service user led research do not appear to have been fulfilled. Instead the focus upon service user's experiences has been the traditional investigation by academics or practitioners of healthcare provider's attitudes towards selfharm, and how these impacts upon primary care (Treloar \& Lewis, 2008; McAllister et al., 2002). The findings of which have merely confirmed the experiences that service users have been highlighting ten years prior to the NICE guidelines (Pembroke, 1994). The authors however posit that service user led research as recommended by the NICE will provide unique experiential insight (Beresford, 2000) in to what is beneficial and what is not, providing increased validation to support and go beyond statistical analysis of rates of self-harm.

Service user involvement (SUI) features in a number of fundamental recommendations in the NICE guidelines including involvement in the commissioning, planning and evaluation of services. This reflects the literature which documents service user's experiences of primary care as often substandard, as confirmed by the lived experiences of individuals who have self-harmed (Pembroke, 1994; LeFevre, 1996). Less well reported however are service user's experiences of secondary healthcare services, particularly those receiving out-patient treatment such as psychosocial therapies.

Given the number of interventions that have been reported to be 'promising' but have not been conclusive the authors wanted to explore whether service users had, to-date, been involved in the evaluation of psychosocial interventions for self-harm and, if so, in what ways. Therefore a systematic review was undertaken specifically with the aim of answering three questions identified by the authors:

1. What contributions have service users made to the evaluation of psychosocial interventions?

2. By what methods have service users been involved? 
3. In what ways could service user involvement supplement empirical evidence for interventions?

It was not the aim to replicate the work of the previous Cochrane review (Hawton, 1999) by commenting upon experimental validity, sample power or the efficacy of the intervention.

\section{Method}

For the purpose of this review Morgan's (1979) definition of self-harm has been slightly adapted to "a non-fatal act, whether physical, drug over dosage or poisoning, done in the knowledge that it was potentially harmful" (p.88). The adaptation being the removal of the word deliberate due to the negative connotations with which it is often associated (see Pembroke, 1994). This definition was chosen to be inclusive of the range of behaviours including, but not limited to, self-laceration, drug overdose, head banging and ligaturing.

All research of therapeutic interventions necessarily 'involve' those who are receiving the intervention by virtue of their consent to participate in research. The definition of involvement for this review however derives from works such as those by Beresford (2000), Faulkner (2004) and Wallcraft \& Nettle (2009) in that 'involvement' aims to empower service users as well as gather and validate their experiences of, in the case of this review, treatment.

Given the individual and cultural factors that may impact upon self-harm (Hjelmeland et al., 2000, 2002) and the use of Morgan's (1979) definition of self-harm the following inclusion criteria laid out in figure 1 were used.

Figure 1 Criteria for Article Inclusion to Guide Selection of Studies 

a) Human Adults (18+)
b) Sample from countries in which a 'western culture' is the dominant culture (i.e. European Countries and Countries marked by European immigration such as North America and Australasia)
c) Post 1979 (consistent with Morgan's definition of self-harm)
d) Self-harm (as defined by Morgan) is the primary focus of the article (i.e. the focus is not substance misuse or eating disorders)
e) Self-harm was not a result of organic or developmental disorders
f) Articles written in English
g) Related to psychosocial interventions. (Given the possible positive impact of opportunities to discuss issues around self- harm (Read, 2007) the authors have defined 'interventions' as including psychosocial assessment and have not limited it to therapies)

Electronic searches were completed on the $28^{\text {th }}$ January 2011 of the Medline (1950-present), Web of Science (1898-Present) and Psychinfo (1979-present) databases using the search terms in table 1.

Table 1. Search Terms Used to Complete Database Searches

\begin{tabular}{|c|c|}
\hline Primary Search-Terms & Secondary Search Term \\
\hline 1. Self-harm ${ }^{*}$ & 6. Intervention* \\
2. Self-injur* & 7. Psychosocial \\
3. Deliberate self-harm & 8. Cognitive \\
4. Parasuicid* & Behavioural Therapy \\
5. Self-mutilation* & (CBT) \\
& 9. Dialectical Behaviour \\
& Therapy (DBT) \\
& 10. Family Therapy \\
& 11. Counselling \\
& 12. Psychother \\
& 13. Art Therapy \\
\hline
\end{tabular}

Primary search terms were initially run alone and then re-run to include each of the secondary search terms, for example $1,1 \& 6,1 \& 7,1 \& 8 \ldots 1 \& 13,2,2 \& 6$, $2 \& 7$ etc. This resulted in 45 searches being completed. 
1440 references were returned and independently sifted in line with the inclusion criteria, discussed and re-sifted by two members of the study team. This was repeated three times until a final consensus of 65 papers were identified for inclusion in the review. The inclusion of papers had to be agreed by both members in order to ensure reasonable inter-rater reliability.

The 65 papers were then independently read by the two member of the research team with notes made in relation to the research questions identified above. Seven of the papers were systematic reviews and/or meta-analysis of interventions. Thematic reviews of qualitative findings were similarly checked and discussed to achieve inter-rater reliability.

\section{Findings}

Table 2 summarises the number of each type of methodology used to investigate interventions in relation to self-harm and the reported significance of the treatment effects in each. A complete table of studies can be found in appendix A. As can be seen 42 (59\%) studies are empirically based and of these only six (8\%) used a mixed methodology to incorporate a qualitative element. Only those studies employing an A-B design, most commonly measuring incidents of self-harm pre and post treatment, used a mixed methodology. Four supplemented quantitative information with interviews and two reported case studies of intervention. 17 (24\%) studies reported a significant treatment effect compared to 26 (37\%) studies which reported nonsignificant treatment effects for the outcome measure of a reduction in selfharm.

Table 3 summarises the seven existing reviews of psych-social intervention. Three types of existing review were identified, meta-analysis, systematic literature review or systematic literature review incorporating meta-analysis. The most common conclusion of the meta-analyses was that sample sizes were too small to evidence treatment effects. Similar findings were reported in a number of individual studies from this review (e.g. Evans et al., 2005; Hepp et al., 2004) 
Table 2 Summary of the Systematic Review

\begin{tabular}{|c|c|c|c|c|c|c|}
\hline $\begin{array}{l}\text { Research } \\
\text { methodology }\end{array}$ & $\begin{array}{l}\text { No. of } \\
\text { studies }\end{array}$ & $\begin{array}{l}\text { No. reporting } \\
\text { significant } \\
\text { treatment } \\
\text { effects }^{4}\end{array}$ & $\begin{array}{l}\text { No. reporting } \\
\text { non-significant } \\
\text { treatment } \\
\text { effect }^{5}\end{array}$ & $\begin{array}{l}\text { No. reporting } \\
\text { no treatment } \\
\text { effect }^{6}\end{array}$ & $\begin{array}{l}\text { No. incorporating } \\
\text { service user } \\
\text { involvement or } \\
\text { experience of treatment }\end{array}$ & Methods used to engage service users \\
\hline RCT & 19 & 5 & 11 & 3 & 0 & $\mathrm{~N} / \mathrm{A}$ \\
\hline A-B design & 14 & 6 & 7 & 1 & 6 & $\begin{array}{l}\text { Interviews (4 studies) } \\
\text { Case studies (2) }\end{array}$ \\
\hline Interview & 6 & 0 & 1 & 2 & $\mathrm{~N} / \mathrm{A}$ & $\mathrm{N} / \mathrm{A}$ \\
\hline Case study & 5 & $\mathrm{~N} / \mathrm{A}$ & 4 & 0 & $\mathrm{~N} / \mathrm{A}$ & $\mathrm{N} / \mathrm{A}$ \\
\hline $\begin{array}{l}\text { Reviews of } \\
\text { interventions }\end{array}$ & $\begin{array}{l}8 \\
\text { reviews }\end{array}$ & $\mathrm{N} / \mathrm{A}$ & $\mathrm{N} / \mathrm{A}$ & $\mathrm{N} / \mathrm{A}$ & 0 & $\mathrm{~N} / \mathrm{A}$ \\
\hline
\end{tabular}

${ }^{4}$ Significant treatment effects are reported statistically significant result in experimental designs and in one case study,

${ }^{5}$ Non-significant treatment effects include research which the authors assert an effect of intervention despite not reaching the requirement of statistical probability. This category also includes empirical studies in which statistical probability is not reported and observed or self-reported change in qualitative designs.

${ }^{6}$ Treatment effect was not always sought in qualitative reports, for example interviews about the functions of self-harm in the course of psychosocial intervention, therefore the figures reporting significant, non-significant or no treatment effects will not sum to the total number of papers included in the review. 
Table 3 Summary of Existing Reviews of Psych-Social Intervention

\begin{tabular}{|c|c|c|c|c|}
\hline Review authors & $\begin{array}{l}\text { Type of } \\
\text { Review } \\
\text { conducted }\end{array}$ & $\begin{array}{l}\text { No. of } \\
\text { studies } \\
\text { included }\end{array}$ & $\begin{array}{l}\text { Type of method } \\
\text { included }\end{array}$ & $\begin{array}{l}\text { Key conclusions } \\
\text { from the review }\end{array}$ \\
\hline $\begin{array}{l}\text { Arensman et al., } \\
(2001)\end{array}$ & $\begin{array}{l}\text { Meta- } \\
\text { analysis }\end{array}$ & 31 & RCT only & $\begin{array}{l}\text { RCTs include too few } \\
\text { participants }\end{array}$ \\
\hline $\begin{array}{l}\text { Arumanayagam et } \\
\text { al., (2004) }\end{array}$ & $\begin{array}{l}\text { Literature } \\
\text { review + } \\
\text { Meta- } \\
\text { analysis }\end{array}$ & $\begin{array}{l}\text { No } \\
\text { information }\end{array}$ & $\begin{array}{l}\text { Empirical including } \\
\text { epidemiological }\end{array}$ & $\begin{array}{l}\text { Evidence based on } \\
\text { single RCT studies } \\
\text { with no replication. } \\
\text { Effect of psychiatric or } \\
\text { community follow-up is } \\
\text { poorly understood. }\end{array}$ \\
\hline Comotois (2002) & $\begin{array}{l}\text { Literature } \\
\text { Review }\end{array}$ & 5 & $\begin{array}{l}\text { Experimental and } \\
\text { quasi-experimental } \\
\text { control trials }\end{array}$ & $\begin{array}{l}\text { Evaluation of } \\
\text { outcomes and staff } \\
\text { training is required. }\end{array}$ \\
\hline $\begin{array}{l}\text { Crawford et al., } \\
\text { (2007) }\end{array}$ & $\begin{array}{l}\text { Literature } \\
\text { Review \& } \\
\text { Meta- } \\
\text { analysis }\end{array}$ & 18 & RCT only & $\begin{array}{l}\text { Many trials had too } \\
\text { few participants. }\end{array}$ \\
\hline Evans (2002) & $\begin{array}{l}\text { Literature } \\
\text { Review }\end{array}$ & $\begin{array}{l}\text { No } \\
\text { information }\end{array}$ & No information & $\begin{array}{l}\text { Unlikely that a single } \\
\text { intervention will prove } \\
\text { effective for all. } \\
\text { A number of trials } \\
\text { should be further } \\
\text { investigated. }\end{array}$ \\
\hline $\begin{array}{l}\text { Hawton et al., } \\
\text { (1999) }\end{array}$ & $\begin{array}{l}\text { Meta- } \\
\text { analysis }\end{array}$ & 23 & RCT only & $\begin{array}{l}\text { Evidence is lacking to } \\
\text { indicate effective } \\
\text { treatment due to too } \\
\text { few participants }\end{array}$ \\
\hline $\begin{array}{l}\text { Hawton et al., } \\
\text { (1998) }\end{array}$ & $\begin{array}{l}\text { Meta- } \\
\text { analysis }\end{array}$ & 20 & RCT only & $\begin{array}{l}\text { Further larger trials are } \\
\text { required. }\end{array}$ \\
\hline $\begin{array}{l}\text { Klonsky \& } \\
\text { Muehlenkamp } \\
\text { (2007) }\end{array}$ & $\begin{array}{l}\text { Literature } \\
\text { Review }\end{array}$ & $\begin{array}{l}\text { No } \\
\text { information }\end{array}$ & No information & $\begin{array}{l}\text { Given the } \\
\text { heterogeneity of the } \\
\text { behaviour } \\
\text { psychotherapy will be } \\
\text { most effective when } \\
\text { self-harm is } \\
\text { understood from the } \\
\text { client's perspective. }\end{array}$ \\
\hline
\end{tabular}




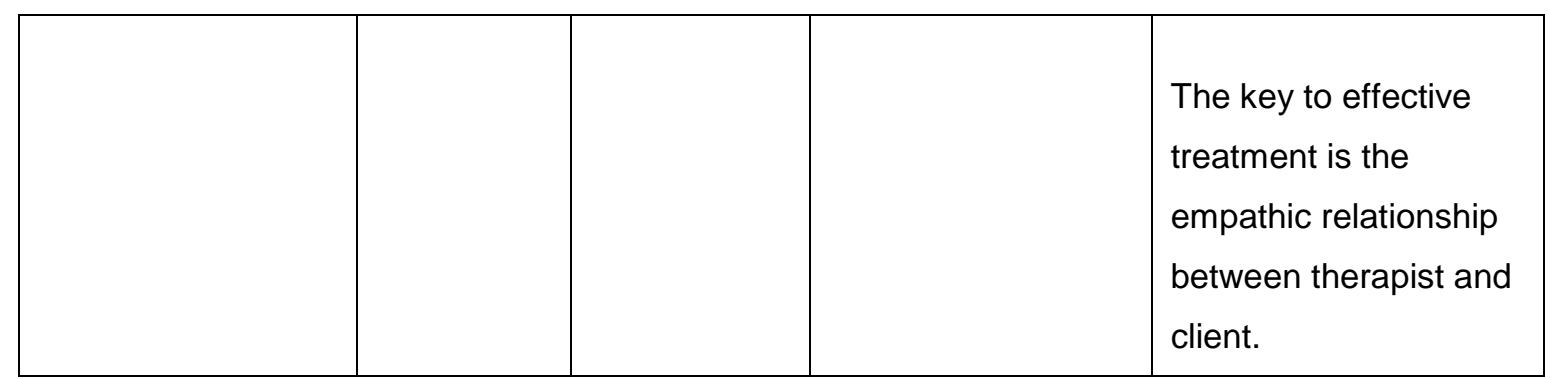

No RCT studies incorporated service user experience of intervention in their analysis. Four RCT studies reported a treatment effect of cognitive behavioural based interventions (including DBT) but concluded they were unable to determine the cause of the effect (Linehan, 1991; Slee et al., 2008; Spinhoven et al., 2009; Weinberg et al., 2006).

Treatment compliance was also a factor that reportedly impacted upon measurement of treatment effect (Congdon \& Clark, 2005). For example only $70(17 \%)$ of 417 participants made use of the crisis card intervention (Evans et al., 2005) whilst attrition rates in one manualised cognitive therapy was reportedly 40\% (Tyrer et al., 2004).

The five case studies all reported service user progress in relation to selfharm during and post intervention. All five reported positive change. Noncoercive, non-judgemental and empowering relationships were reported by services users to be instrumental in effecting change. Whether these be with individual therapists (Brown \& Bryant, 2007; Levy, Yeomans \& Diamond, 2007; Malon \& Beradi, 1987) or through group peer support (Concoran et al., 2007; Katz \& Levendusky, 1990). The importance of client-therapist relationships were also echoed by qualitative studies examining the reasons for desistance of self-harm in those who had already done so (Kool, van Meijel \& Bosman, 2009; Shaw, 2006; Zich, 1984) and in mixed methodological designs of intervention efficacy (Cremin et al., 1995; Low et al., 2001)

Methodologies included in the 'other' category in Table 2 included an action research approach for the development of psycho-social assessment of selfharm (McElroy \& Sheppard, 1999) a Delphi process with service users and healthcare professionals in the development of guidelines relating to self-harm (Kelly, et al., 2008) and two audit processes of pathways of care both of which 
highlight a need for adequate psycho-social assessment in primary care to improve outcomes for service users (Kapur et al., 2008; Kriplani et al., 2010).

\section{Discussion}

The purpose of this systematic literature review was not to identify or recommend interventions for self-harm, nor critique the methodology or findings of previous research. This has previously been done (Hawton et al., 1999; Arensman et al., 2001; Crawford et al., 2007) and recommendations made. The review rather stemmed from such meta-analyses which consistently fail to definitively report effective interventions, usually due to insufficient sample sizes (Hawton et al., 1999) or due to participants in trials not being 'homogenous' enough (Arensman et al., 2001). Small participant populations are surprising given the large numbers of patients who present to healthcare providers following an episode of self-harm (Brier \& Gill, 2003) however may reflect a population that is difficult to engage in scientific research, possibly as a result of the stigma that service users often feel following self-harm (Balsam et al., 2005). This suggests that, perhaps, randomised clinical control trials are not the most effective way of evaluating psychosocial interventions for self-harm. With regards of the confounding variable of heterogeneity surely diversity in people who self-harm needs to be accounted for in interventions if they are to prove effective? As such the purpose of this review was to consider the extent of the use of other methods for evaluation and in particular to what extent have the experiences of service users been incorporated into evaluation studies. We shall consider this in the framework of the three questions posed earlier.

\section{What contributions have service users made to the evaluation of psychosocial interventions?}

The literature search reveals that the majority $(69 \%)$ of studies $(n=61)$ used an experimental or quasi-experimental design, with just six of these employing mixed methodologies. 11 sought to engage service users through qualitative methods including interviews and case studies involving participant checking. 
All studies using an empirical design used repetition of self-harm as an outcome measure. This outcome measure however may represent an artifact of the experimental process given that service users do not consider cessation of self-harm to be a useful treatment target (Kelly et al., 2008). Previous literature has suggested that repetition (or more commonly representation at primary care services) should just be one measure amongst others that consider holistically how intervention may impact upon other aspects of the service users quality of life (Kapur, 2005). The expectation of total abstinence from self-harm negates the importance of the behaviour as a coping or survival strategy for those who use it (Cresswell, 2005; Pembroke, 1994). These outcome measures are also at odds with those for service users who demonstrate other high risk behaviours such as substance misuse in which, although cessation may ultimately be the desired outcome, safer behaviours such as using sterilised equipment or methadone programmes are also widely accepted as indicators of treatment efficacy (McDermott, 1997).

Where service user's narratives have been included either through qualitative or mixed methodologies it is rarely the intervention per se that features as important for the individual. With the exception of Eccelston and Sorrbello (2002) who reported that those taking part in the adapted version of DBT stated the intervention improved emotional management and relieved symptoms of depression and anxiety. More commonly however treatment effects were attributed to the relationship the service user had with the service provider (Kool, van Meijel \& Bosman, 2009; Cremin et al., 1995; Brown \& Bryant, 2007). Collaborative and non-coercive relationships were reported to be most beneficial (Shaw, 2006) as were ones that validated the service users experiences (Low et al., 2001). This is not a new finding with Nelson and Grunebaum (1971) reporting an 'equal' patient-doctor relationship as being the most important aspect in the treatment of self-harm. This finding however that appears to have been lost or overlooked in the majority of efficacy studies. 


\section{By what methods have service users been involved?}

The review provides evidence that the involvement of service users is far from common practice in the research literature. This is despite the NICE guidelines recommending

"User-led, qualitative research into the experience and views of people who self-harm... examining the benefits and adverse consequences of the services they receive and the treatments they have undertaken" (p.179)

Where service user's experiences of interventions have been explored, either through qualitative or mixed methodologies, this is commonly in the form of case studies (e.g. Congdon \& Clarke, 2005; Wallenstein \& Nock, 2007). Interview and semi-structured interviews were also commonly used (e.g. Klonsky \& Glenn, 2008). No accounts of service user consultation or involvement let alone user led research in the design or conducting of research was found from the searches. One study (McElroy \& Sheppard, 1999) reported the use of an action research project to develop policy in the assessment and management of self-harm in an Accident and Emergency department. However the involvement did not extend to include service users despite the different perspectives this would have contributed (Maddock et al., 2004) and the emphasis on service user involvement being a significant feature of mental health policy since the National Service Framework was introduced in 1999 (Bailey, 2011).

\section{In what ways could service user involvement supplement empirical evidence for interventions?}

From the results of this review the authors suggest that empirical research into the efficacy of psychosocial interventions for self-harm would benefit from more systematic involvement of service users in a number of ways.

Firstly a number of studies report a treatment effect but are unable to determine which particular aspects of the intervention are most useful 
(Linehan, 1991; Slee et al., 2008; Spinhoven et al., 2009; Weinberg et al., 2006). Given the expertise and unique perspective of those with lived experience (Beresford, 2000; Maddock et al., 2004) involving service users to answer the question of what is and what is not useful about intervention is likely to be enlightening. Lamprech et al., (2007) in their study of solution focussed behavioural therapy for self-harm concluded that the approach has shifted the philosophy of therapies for self-harm towards "the patient as expert on themselves". This was despite not involving service users in their research. In addition to interviews data collection methods could include therapy diaries in which service users could reflect on aspects of the therapy. This method is commonly used in cognitive-behaviour based interventions for substance misuse (McMurran, 2007). Such techniques could be equally useful in research which does not recruit sufficient participants to reach statistical power despite showing some treatment effect (e.g. Evans et al., 2005; Hepp et al., 2004).

Secondly, a number of studies suffered from high attrition rates or poor treatment compliance (e.g. Evans et al., 1999; Crawford \& Wessely, 2000; Tyer et al., 2003, 2004). All three of these studies related to therapies delivered at a distance, for example the use of telephone help lines, provision of a 'green card' allowing access to services or self administered manualised cognitive behavioural therapies. Given the reports of the importance of therapeutic relationships to clients previously discussed it could be postulated that high attrition may be a result of the lack of relationship building these approaches take. Again the involvement of service users who receive such interventions could uncover any reasons for treatment non-completion. In one instance (Beautrais et al., 2010) postcard intervention trials had to be stopped due to staff reluctance to employ the technique, despite some effect for selfpoisoning being found. Qualitative enquiry to uncover the reasons for staff reluctance as well as client's experiences would be useful in such instances.

The authors recognise that the recommendations made for increased service user involvement make a number of assumptions. One assumption is that service users are able to fully understand and articulate reasons for their selfharming behaviour. Given that emotional inexpressivity is associated with 
more frequent self-harm (Gratz, 2006) it may be expected that those accessing services be less able to articulate how intervention impacts upon their self-harming behaviour or complete tools such as diaries. The authors would argue however that this is simply an issue of ensuring data collection methods are responsive to the needs of the service user to guarantee differing styles of communication are catered for (Ward \& Bailey in press). It is also worth noting that those studies which utilised interviews or participant checking did not report any difficulties in the use of these methods.

Another assumption is that service users would engage in research which actively seeks to involve them. Feelings of stigma or shame (Balsam et al., 2005) or attitudes to self-harm encountered during care (Kenning et al., 2010; Pembroke, 1994) may act as barriers to engagement. Again this was not reported in the studies that employed data collections techniques such as interviews. Nor is this the finding of participatory action research projects which have sought to engage and empower service users (Ward \& Bailey, 2011)

The findings of the literature review do not account for all the ways in which service users can be involved in the services which they access. Studies were not included which described or evaluated the development of staff training packages with the involvement of service users (e.g. Rea et al., 1997). The authors acknowledge that service user consultation is often a feature of service development however the results of the current review indicate that this could be further expanded to the evaluation of interventions for self-harm.

To summaries the recommendations the authors endorse for future research include:

- The involvement of service users in the design and implementation of research to ensure outcome measures are meaningful and representative of personal treatment goals.

- The use of mixed methodologies to explore service user's experiences of psychosocial interventions and what they find helpful and unhelpful. 
This may be particularly useful in the development of interventions which seek to address the 'underlying social issues' that surround selfharm (RCP, 2010).

- Further exploration of the way in which professional relationships can be fostered through interventions which show promise such as CBT and DBT and also distance interventions such as postcard therapy.

- The use of participatory action research approaches in the development of services and particularly secondary mental health interventions. It is anticipated that such an approach would promote a sense of ownership and possible improve service uptake (Foster et al., 2005)

\section{Conclusion}

Definitively effective psycho-social interventions for self-harm remain elusive. This however may be an artifact of the consistent failure to actively involve service users in efficacy research. The use of repetition of self-harm as an outcome measure is considered an invalid measurement of success by those who self-harm. Interventions that do report some degree of treatment effect suffer from lack of statistical power and an inability to pin point the effective aspects of treatment whilst others suffer from high attrition rates. The involvement and collection of user narratives would however provide depth of validity to empirical research and provide insight in to what is helpful in the management of self-harm or provide reasons for high drop out rates. Developing the concept of involvement further to empower service users to lead research and subsequent service design will promote ownership and uptake of services and may positively impact upon treatment efficacy. 


\section{References}

Bailey, D. (2011) Interdisciplinary Working in Mental Health. London: Palgrave Macmillan.

Balsam, K. F. Beauchaine, T. P. Mickey, R. M. and Rothblum, E.D. (2005) Mental Health of Lesbian, Gay, Bisexual and Heterosexual Siblings: The Effects of Gender, Sexual Orientation, and Family. Journal of Abnormal Psychology, 114, 471-6

Beresford P (2000) Service users 'knowledge' and social work theory: Conflict or collaboration. British Journal of Social Work, 30, 489-503

Briere J \& Gil E (1998) Self-mutilation in clinical and general population samples: prevalence, correlates, and functions. American Journal of Orthopsychiatry 68 609-620

Cresswell, M. (2006) 'Self-Harm: Perspectives from Personal Experience' an appreciation'. Available at: http://www.studymore.org.uk/cress3.pdf accessed 16th August 2011

Crowe, M., \& Bunclark, J. (2000) Repeated self-injury and its management. International Review of Psychiatry 12 48-53.

Foster, J., Tyrell, K., Cropper, V., \& Hunt, N. (2005). Welcome to the Team...Service Users in Staff Recruitment. Drink and Drugs News. 21

Hawton, K., Kirk, J. (1989) Problem-solving. In: Hawton, K., Salkovskis, P., Kirk, J., Clark, D. M. (eds). Cognitive behaviour therapy for psychiatric problems: A practical guide. Oxford: Oxford University Press, 406-26.

Hawton, K. K. E., Townsend, E., Arensman, E., Gunnell, D., Hazell, P., House, A., van Heeringen, K. (1999) Psychosocial and pharmacological 
treatments for deliberate self-harm. Cochrane Database of Systematic Reviews, Issue 4.

Hjelmeland, H., Nordvik, H., Bille-Brahe, U., et al., (2000) A cross-cultural study of suicide intent in parasuicide patients. Suicide and Life-Threatening Behaviour, 30(4), 295-303

Hjelmeland, H., Hawton, K., Nordvik, H., et al., (2002) Why people engage in parasuicide: a crosscultural study of intentions. Suicide and Life-Threatening Behaviour, 32(4), 380-393.

Leader, A. (1998) Power Tools: A Resource Pack For Those Committed To The Development Of Mental Health Advocacy Into The Millennium. Brighton: Pavilion.

LeFevre, S. (1996). Killing me softly: Self-harm, survival not suicide. Gwynedd: Handsell Publications.

Linehan, M. M., Armstrong, H. E., Suarez, A., Allmon, D., \& Heard, H. L. (1991). Cognitive- behavioural treatment of chronically parasuicidal borderline patients. Archives of General Psychiatry, 48, 1060-1064.

Kapur, N. (2005) Management of self-harm in adults: which way now? British Journal of Psychiatry, 187, 497-499.

Kenning, C., Cooper, J., Short, V., Shaw, J., Abel, K., \& Chew-Graham, C., (2010) Prison staff and women prisoner's views on self-harm; their implications for service delivery and development: A qualitative study. Criminal Behaviour and Mental Health, 20 (4), 274-284

Klonsky, D. E. (2007) The functions of deliberate self-injury: A review of the evidence. Clinical Psychology Review 27 226-239. 
Maddock, J., Lineham, D., \& Shears, J. (2004) Empowering mental health research: user-led research into the care programme approach. Policy and Planning, 22 (2) 15-22.

McAllister, M., Creed, D., Moyle, W., \& Farrugia, C. (2002) Nurses' attitudes towards clients who self-harm. Journal of Advanced Nursing 40 (5) 578-586

McDermott, P. (1997) Will drug users respond to the challenge? Drug Edition available at: http://www.drugtext.org/pdf/Self-help-peer-support-andoutreach/will-drug-users-respond-to-the-challenge.pdf (accessed 18th August 2011).

McMurran, M. (2007) What works in substance misuse treatment for offenders? Criminal Behaviour and Mental Health, 17(4), 225-233

Morgan, H.G. (1979) Death Wishes: Assessment and Management of Deliberate Self-Harm. Chichester, Wiley

Nelson, S. H., \& Grunebaum, H. (1971). A follow-up study of wrist slashers. American Journal of Psychiatry, 127, 1345-1349

Nock, M. K., \& Prinstein, M. J. (2004) A functional approach to the assessment of self-mutilative behavior. Journal of Consulting and Clinical Psychology 72 885-890.

Pembroke, L. (Ed.). (1994) Self-harm: Perspectives from personal experience. London: Survivors Speak Out.

Prinstein, M. J. (2008) A review of unique challenges and important directions for self-injury science. Journal of Consulting and Clinical Psychology, 76(1), $1-8$

Read, J. (2007) To ask or not to ask about abuse. New Zealand research. American Psychologist, May-June, 327-328. 
Ringel, S., \& Brandell, J.R. (eds) (2011) Trauma: Contemporary directions in theory, practice and research. Thousand Oaks: Sage

Roberts, B. (2002) Biographical Research. Buckingham: Open University Press.

Royal College of Psychiatrists (2008b) Better Services for People who SelfHarm. Wave 3 Baseline Data - Key Finding and Recommendations. London: Author. Available at:

www.rcpsych.ac.uk/pdf/Aggregated\%20W3\%20Report\%20Summary. pdf (accessed 22nd June 2011).

Simpson, A. E. (2004) The lived experience of self-harm and recovery from self-harm: a co-grounded theory. Unpublished PhD Thesis. In Simpson A (2006) Can mainstream health services provide meaningful care for people who self-harm? A critical reflection. Journal of Psychiatric and Mental Health Nursing 13 429-436.

Tantam, D., \& Hubband, N. (eds) (2009) Understanding Repeated Self-injury: A Multidisciplinary Approach. Basingstoke: Palgrave MacMillan.

Treloar, A. J. C., \& Lewis, A. J. (2008) Professional attitudes towards deliberate self-harm in patients with borderline personality disorder. Australian and New Zealand Journal of Psychiatry 42(7) 578-584.

Spirito, A., \& Esposito-Smythers, C. (2006). Addressing adolescent suicidal behavior: Cognitive- behavioural strategies. In P. C. Kendall (Ed.), Child and adolescent therapy: Cognitive-behavioural procedures (3rd ed., pp. 217242). New York: Guilford Press

Wallcraft, J. and Nettle, M. (2009) History, Context and Language. In J. Wallcraft, B. Schrank and M. Amering (eds) Handbook of Service User Involvement in Mental Health Research. John Wiley \& Sons: Chichester. 
Ward, J., \& Bailey, D. (in press) At Arms Length: The Development of a SelfInjury Training Package for Prison Staff through Service User Involvement. Journal of Mental Health Education, Training and Practice.

Whitlock, J. L., Eells, G., Cummings, N., \& Purington, A. (2007) Trends in college mental health and self-injurious behavior: Findings form a national survey of college mental health providers. Under Review.

Zahl, D. L., \& Hawton, K. (2004) Repetition of deliberate self-harm and subsequent suicide risk: Long-term follow-up study of 11,583 patients. British Journal of Psychiatry, 185(1): 70-75 


\section{Appendix A}

\begin{tabular}{|c|c|c|c|c|c|c|c|c|c|c|}
\hline & $\begin{array}{l}\text { Author } \\
\text { s }\end{array}$ & Year & Journal & $\begin{array}{l}\text { Gender } \\
\text { of } \\
\text { participa } \\
\text { nt }\end{array}$ & $\begin{array}{l}\text { Samp } \\
\text { le } \\
\text { Size }\end{array}$ & $\begin{array}{l}\text { Representativene } \\
\text { ss? (comments) }\end{array}$ & $\begin{array}{l}\text { Methods } \\
\text { used to } \\
\text { investigat } \\
\quad \text { e } \\
\text { interventi } \\
\text { on (RCT, } \\
\text { Qual, etc) }\end{array}$ & $\begin{array}{l}\text { Outcome } \\
\text { measure }\end{array}$ & $\begin{array}{l}\text { Limitations } \\
\text { identified by } \\
\text { authors }\end{array}$ & $\begin{array}{l}\text { Comments (how has PAR methods differed from } \\
\text { positivistic approaches? Might PAR address some of } \\
\text { the limitations of the study?) }\end{array}$ \\
\hline 1. & Aoun & 1999 & $\begin{array}{l}\text { Australia } \\
\mathrm{n} \text { and } \\
\text { New } \\
\text { Zealand } \\
\text { Journal } \\
\text { of } \\
\text { Mental } \\
\text { Health } \\
\text { Nursing }\end{array}$ & $\begin{array}{c}\text { Male } \\
38 \% \\
\\
\text { Female } \\
62 \%\end{array}$ & 208 & $\begin{array}{l}\text { Age of patients } \\
\text { ranged from } 12-66 \\
\text { years. }\end{array}$ & $\begin{array}{c}\text { Non- } \\
\text { randomize } \\
d \\
\text { interventio } \\
n \text { trial }\end{array}$ & $\begin{array}{l}\text { The number } \\
\text { of } \\
\text { reattempts } \\
\text { of self harm } \\
\text { or suicide }\end{array}$ & & $\begin{array}{l}\text { High intervention significantly reduces hospitalization. } \\
15-24 \text { age groups had highest proportion of risk of self harm, } \\
\text { with attempts and risk steadily declining with age. } \\
\text { Employed a suicide prevention counselor to provide } \\
\text { intensive outreach and professional and community based } \\
\text { education for intervention strategies. }\end{array}$ \\
\hline 2. & $\begin{array}{l}\text { Arens } \\
\text { man et } \\
\text { al }\end{array}$ & 2001 & $\begin{array}{c}\text { Suicide } \\
\text { and Life } \\
\text { Threaten } \\
\text { ing } \\
\text { Behavior }\end{array}$ & $\mathrm{N} / \mathrm{A}$ & $\begin{array}{l}31 \\
\text { report } \\
\text { s in } \\
\text { total }\end{array}$ & $\begin{array}{l}\text { RCTs } \\
\quad(25) \\
\text { Nonrandomized } \\
\text { clinical trials } \\
\quad(6)\end{array}$ & $\begin{array}{c}\text { Systemati } \\
\text { c review of } \\
\text { the } \\
\text { effectivene } \\
\text { ss of RCT } \\
\text { treatments } \\
\text { Effectiven } \\
\text { ess and } \\
\text { quality of } \\
\text { the RCT } \\
\text { was } \\
\text { assessed. }\end{array}$ & $\begin{array}{c}\text { Treatment } \\
\text { for DSH that } \\
\text { have been } \\
\text { used over } \\
\text { the past } 30 \\
\text { years that } \\
\text { have used } \\
\text { RCTs. } \\
\text { Repetition of } \\
\text { DSH }\end{array}$ & $\mathrm{N} / \mathrm{A}$ & $\begin{array}{l}\text { Limitations of past RCTs included too few participants to } \\
\text { detect clinically important differences in rates of repeated } \\
\text { self-harm. } \\
\text { Future trials should include calculations to determine the } \\
\text { number of subjects necessary to detect clinical effects; } \\
\text { provide information on methods of randomization and } \\
\text { interventions; use standard measures of outcome; focus on } \\
\text { homogeneous subgroups of patents. }\end{array}$ \\
\hline
\end{tabular}




\begin{tabular}{|c|c|c|c|c|c|c|c|c|c|c|}
\hline U. & $\begin{array}{l}\text { Arnevi } \\
\mathrm{k} \text { et al }\end{array}$ & 2009 & $\begin{array}{c}\text { Europea } \\
\text { n } \\
\text { Psychiat } \\
\text { ry }\end{array}$ & $\begin{array}{l}\text { Not } \\
\text { stated }\end{array}$ & 114 & $\begin{array}{c}\text { Only patients with } \\
\text { PDs were included } \\
\text { in the study. } \\
\text { Exclusion criteria } \\
\text { were schizotypal } \\
\text { PD, antisocial PD, } \\
\text { ongoing } \\
\text { alcohol or drug } \\
\text { dependence, } \\
\text { psychotic } \\
\text { disorders, bipolar I } \\
\text { disorder, untreated } \\
\text { ADHD (adult type), } \\
\text { pervasive } \\
\text { developmental } \\
\text { disorder (e.g., } \\
\text { Asperger's } \\
\text { syndrome), organic } \\
\text { syndromes, and } \\
\text { being homeless. } \\
\text { } 60 \text { patients in Day } \\
\text { Hospital } \\
\text { Psychotherapy and } \\
54 \text { in Outpatient } \\
\text { Individual } \\
\text { Psychotherapy. }\end{array}$ & RCT & $\begin{array}{l}\text { attrition rate, } \\
\text { suicide } \\
\text { attempts, } \\
\text { suicidal } \\
\text { thoughts, } \\
\text { self-injury, } \\
\text { psychosocial } \\
\text { functioning, } \\
\text { symptom } \\
\text { distress, and } \\
\text { interpersonal } \\
\text { and } \\
\text { personality } \\
\text { problems. }\end{array}$ & $\begin{array}{l}\text { Changes over time } \\
\text { may be due to } \\
\text { natural recovery } \\
\text { process, not } \\
\text { treatment. } \\
\text { No treatment } \\
\text { group, so change } \\
\text { may not be } \\
\text { attributed to } \\
\text { treatment. } \\
\text { Staff were not } \\
\text { allowed to be as } \\
\text { 'confrontational' as } \\
\text { in a usual session } \\
\text { to avoid drop out. }\end{array}$ & \\
\hline 4. & $\begin{array}{l}\text { Aruma } \\
\text { nayaga } \\
m \text { et al }\end{array}$ & 2004 & $\begin{array}{l}\text { Australia } \\
\mathrm{n} \text { and } \\
\text { New } \\
\text { Zealand } \\
\text { Journal } \\
\text { of } \\
\text { Psychiat } \\
\text { ry }\end{array}$ & $\mathrm{N} / \mathrm{A}$ & $\mathrm{N} / \mathrm{A}$ & $\begin{array}{l}\text { Literature review } \\
\text { on treatment for } \\
\text { deliberate self } \\
\text { harm. }\end{array}$ & $\begin{array}{c}\text { Literature } \\
\text { review + } \\
\text { meta } \\
\text { analysis }\end{array}$ & & & $\begin{array}{l}\text { Evidence for the effectiveness of psychological treatments is } \\
\text { based on single RCTs without replication. }\end{array}$ \\
\hline b. & $\begin{array}{c}\text { Atha et } \\
\text { al }\end{array}$ & 1992 & $\begin{array}{l}\text { Journal } \\
\text { of } \\
\text { Psychos } \\
\text { omatic } \\
\text { Researc } \\
\mathrm{h}\end{array}$ & $\begin{array}{c}\text { Male } \\
(16) \\
\text { Female } \\
(16)\end{array}$ & 32 & $\begin{array}{l}\text { Patients showing } \\
\text { characteristic } \\
\text { related to } \\
\text { psychopathy and } \\
\text { repeated } \\
\text { attendance at a }\end{array}$ & $\begin{array}{l}\text { RCT } \\
\text { Randomly } \\
\text { allocated } \\
\text { to either } \\
\text { TREATME }\end{array}$ & $\begin{array}{l}\text { Reduction in } \\
\text { hospital } \\
\text { attendances } \\
\text { through } \\
\text { identifying } \\
\text { and solving }\end{array}$ & $\begin{array}{c}\text { The patents were } \\
\text { not a specific } \\
\text { group. }\end{array}$ & \\
\hline
\end{tabular}




\begin{tabular}{|c|c|c|c|c|c|c|c|c|c|c|}
\hline & & & & & & $\begin{array}{c}\text { medical } \\
\text { emergency facility }\end{array}$ & $\begin{array}{l}\text { NT AS } \\
\text { USUAL or } \\
\text { PSYCHOL } \\
\text { OGICAL } \\
\text { TREATME } \\
\text { NT }\end{array}$ & $\begin{array}{c}\text { patient } \\
\text { problems. }\end{array}$ & & \\
\hline 6. & $\begin{array}{l}\text { Beautr } \\
\text { ais et } \\
\text { al }\end{array}$ & 2010 & $\begin{array}{l}\text { The } \\
\text { British } \\
\text { Journal } \\
\text { of } \\
\text { Psychiat } \\
\text { ry }\end{array}$ & $\begin{array}{l}\text { Male \& } \\
\text { Female }\end{array}$ & $\begin{array}{c}700 \\
\\
\text { (350 } \\
\text { contro } \\
\text { I } \\
\text { group, } \\
350 \\
\text { interv } \\
\text { ention } \\
\text { ) }\end{array}$ & $\begin{array}{l}\text { Individuals who } \\
\text { were } 16 \text { or older } \\
\text { and were } \\
\text { presented to } \\
\text { psychiatry } \\
\text { emergency } \\
\text { services following } \\
\text { self-harm or } \\
\text { attempted suicide. }\end{array}$ & $\begin{array}{c}\text { RCT } \\
\text { To } \\
\text { examine } \\
\text { whether a } \\
\text { postcard } \\
\text { interventio } \\
\text { n reduces } \\
\text { self-harm } \\
\text { representa } \\
\text { tions in } \\
\text { individuals } \\
\text { presenting } \\
\text { to the } \\
\text { emergenc } \\
y \\
\text { departmen } \\
\text { ts }\end{array}$ & $\begin{array}{c}\text { The } \\
\text { proportion of } \\
\text { participants } \\
\text { re- } \\
\text { presenting } \\
\text { with self } \\
\text { harm and } \\
\text { the number } \\
\text { of re- } \\
\text { presentation } \\
s \text { for self- } \\
\text { harm in the } \\
\text { months } \\
\text { following the } \\
\text { initial } \\
\text { presentation. }\end{array}$ & $\begin{array}{l}\text { The trial was } \\
\text { stopped early after } \\
8 \text { months due to } \\
\text { the reluctance of } \\
\text { staff to recruit } \\
\text { individuals to the } \\
\text { trial. } \\
\text { Despite strong } \\
\text { randomization, the } \\
\text { distribution of prior } \\
\text { self-harm } \\
\text { visitations to the } \\
\text { hospital appeared } \\
\text { to be skewed. This } \\
\text { meant that a group } \\
\text { of participants with } \\
\text { very high history of } \\
\text { self-harm were } \\
\text { clustered in one } \\
\text { experimental } \\
\text { group - affecting } \\
\text { overall rates. }\end{array}$ & $\begin{array}{l}\text { Postcard intervention did not significantly reduce self-harm. } \\
\text { Postcard intervention is more effective following self- } \\
\text { poisoning. }\end{array}$ \\
\hline 7. & $\begin{array}{c}\text { Benne } \\
\text { with et } \\
\text { al }\end{array}$ & 2002 & $\begin{array}{l}\text { British } \\
\text { Medical } \\
\text { Journal }\end{array}$ & $\begin{array}{l}\text { Male and } \\
\text { Female }\end{array}$ & 1932 & $\begin{array}{l}\text { patients registered } \\
\text { with the study } \\
\text { practices who had } \\
\text { attended accident } \\
\text { and emergency } \\
\text { departments at one } \\
\text { of the four } \\
\text { hospitals after an } \\
\text { episode of } \\
\text { deliberate self } \\
\text { harm. }\end{array}$ & $\begin{array}{l}\text { Cluster } \\
\text { RCT }\end{array}$ & $\begin{array}{l}\text { Primary } \\
\text { outcome } \\
\text { was } \\
\text { occurrence } \\
\text { of a repeat } \\
\text { episode of } \\
\text { deliberate } \\
\text { self harm } \\
\text { in the } 12 \\
\text { months after } \\
\text { the index } \\
\text { episode. } \\
\text { Secondary }\end{array}$ & $\begin{array}{c}\text { did not } \\
\text { reduce the } \\
\text { incidence of repeat } \\
\text { self harm. } \\
\text { a short delay } \\
\text { occurred between } \\
\text { the } \\
\text { index episode and } \\
\text { the general } \\
\text { practitioner } \\
\text { receiving } \\
\text { the letter and }\end{array}$ & $\begin{array}{l}\text { The intervention had no significant effect on patterns of } \\
\text { repetition of deliberate self harm. If anything, the risk of } \\
\text { repetition was slightly higher in the intervention group than in } \\
\text { the control group. }\end{array}$ \\
\hline
\end{tabular}




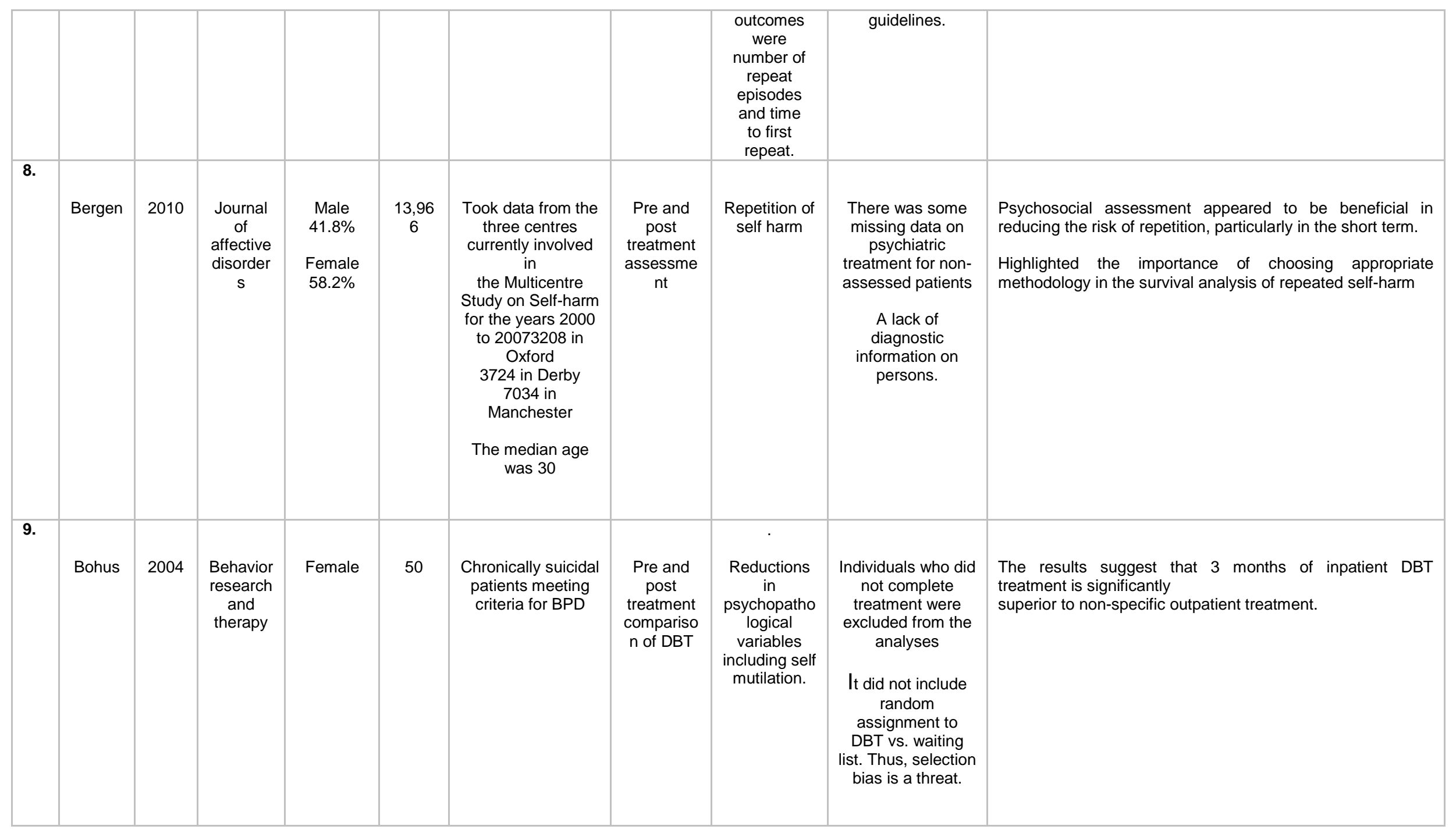




\begin{tabular}{|c|c|c|c|c|c|c|c|c|c|c|}
\hline & $\begin{array}{l}\text { Brown } \\
\& \\
\text { Bryan }\end{array}$ & 2007 & $\begin{array}{l}\text { Journal } \\
\text { of } \\
\text { Clinical } \\
\text { Psycholo } \\
\text { gy }\end{array}$ & Female & $\begin{array}{c}1 \\
\text { (case } \\
\text { study) }\end{array}$ & $\begin{array}{c}32 \text { years old } \\
\text { Euro American } \\
\text { Poverty stricken } \\
\text { Physical abuse } \\
\text { from mother } \\
\text { Sexual abuse from } \\
\text { father } \\
\text { Sexually exploited } \\
\text { and trafficked from } \\
\text { a young age } \\
\text { Foster care } \\
\text { Prostitution in late } \\
\text { teens } \\
\text { Experience sexual } \\
\text { harassment in } \\
\text { work } \\
\text { Triggered post } \\
\text { traumatic } \\
\text { symptoms }\end{array}$ & $\begin{array}{l}\text { Feminist } \\
\text { psychothe } \\
\text { rapy } \\
\text { approache } \\
\text { s to self } \\
\text { harming } \\
\begin{array}{l}\text { Longitudin } \\
\text { al }\end{array} \\
\text { (10 years) }\end{array}$ & $\begin{array}{l}\text { Taking } \\
\text { independent } \\
\text { control of } \\
\text { her life and } \\
\text { controlling } \\
\text { the self } \\
\text { harm. }\end{array}$ & & Feminist theory/ approach \\
\hline 11. & $\begin{array}{l}\text { Byford } \\
\& \\
\text { Knapp }\end{array}$ & 2003 & $\begin{array}{l}\text { Psycholo } \\
\text { gical } \\
\text { Medicine }\end{array}$ & $\begin{array}{l}\text { Male \& } \\
\text { Female }\end{array}$ & 397 & $\begin{array}{l}\text { All had a history of } \\
\text { reoccurring } \\
\text { deliberate self } \\
\text { harm }\end{array}$ & $\mathrm{RCT}$ & $\begin{array}{l}\text { No. of } \\
\text { patients } \\
\text { having a } \\
\text { repeat } \\
\text { episode of } \\
\text { deliberate } \\
\text { self harm } \\
\text { and their } \\
\text { quality of life }\end{array}$ & $\begin{array}{l}\text { Quality of life } \\
\text { results were not } \\
\text { conclusive. }\end{array}$ & $\begin{array}{l}\text { Although the results presented here are not entirely } \\
\text { conclusive, exploration of the uncertainty surrounding the } \\
\text { relative costs and effects suggests that there is at least a } \\
90 \% \text { probability that MACT is a more cost-effective strategy } \\
\text { for reducing the recurrence of deliberate self-harm in this } \\
\text { population over } 12 \text { months than treatment as usual, and the } \\
\text { relative brevity of the treatment, its use of existing therapists, } \\
\text { and the easy applicability of the intervention in a service } \\
\text { context, make a strong case for its selection. }\end{array}$ \\
\hline 12. & $\begin{array}{l}\text { Carter } \\
\text { et al }\end{array}$ & 2010 & $\begin{array}{l}\text { Australia } \\
\text { n \& New } \\
\text { Zealand } \\
\text { Journal } \\
\text { of }\end{array}$ & Female & 73 & $\begin{array}{l}\text { All met criteria for } \\
\text { BPD }\end{array}$ & RCT & $\begin{array}{l}\text { Outcomes } \\
\text { measured } \\
\text { after } 6 \\
\text { months. }\end{array}$ & $\begin{array}{l}\text { Too short } \\
\text { comparison } \\
\text { duration time- } \\
\text { other studies } \\
\text { suggest } 12-18\end{array}$ & $\begin{array}{l}\text { Primary outcomes: } \\
* \quad \text { differences in proportion and rates of DSH } \\
\quad \text { hospital admission for DSH or psychiatric } \\
\text { condition } \\
* \quad \text { Difference in length of stay in hospital. }\end{array}$ \\
\hline
\end{tabular}




\begin{tabular}{|c|c|c|c|c|c|c|c|c|c|c|}
\hline & & & $\begin{array}{l}\text { Psychiat } \\
\text { ry }\end{array}$ & & & & & $\begin{array}{l}\text { Both primary } \\
\text { and } \\
\text { secondary } \\
\text { outcome } \\
\text { measures } \\
\\
{ }^{*} \text { See } \\
\text { comment } \\
\text { box }\end{array}$ & months & $\begin{array}{l}\text { Secondary outcomes: } \\
* \quad \text { Disability and quality of life measures }\end{array}$ \\
\hline 13. & $\begin{array}{c}\text { Chiesa } \\
\& \\
\text { Fonag } \\
y\end{array}$ & 2007 & $\begin{array}{l}\text { Psychot } \\
\text { herapy } \\
\text { and } \\
\text { Psychos } \\
\text { omatics }\end{array}$ & $\begin{array}{c}\text { Male } \\
25 \% \\
\\
\text { Female } \\
75 \%\end{array}$ & 137 & $\begin{array}{c}\text { Inclusion criteria: } \\
\text { (Aged between 19- } \\
55 \text { years; IQ>80; } \\
\text { Presence of at } \\
\text { least on PD) } \\
\\
\text { Exclusion criteria: } \\
\text { (Diagnosed } \\
\text { schizophrenics; } \\
\text { psychoactive } \\
\text { substance } \\
\text { addiction; evidence } \\
\text { of an organic brain } \\
\text { disorder). }\end{array}$ & $\begin{array}{c}\text { Predictor } \\
\text { analysis } \\
\text { Structured } \\
\text { interview } \\
\text { based on } \\
\text { the } \\
\text { Suicide } \\
\text { and Self } \\
\text { Harm } \\
\text { inventory } \\
\text { was } \\
\text { applied to } \\
\text { obtain } \\
\text { details of } \\
\text { self harm } \\
\text { episodes, } \\
\text { number } \\
\text { and length } \\
\text { of } \\
\text { psychiatric } \\
\text { inpatient } \\
\text { episodes } \\
\text { and of } \\
\text { psychiatric } \\
\text { outpatient } \\
\text { attendanc } \\
\text { e. }\end{array}$ & $\begin{array}{l}\text { Outcome } \\
\text { was } \\
\text { assessed in } \\
\text { the three } \\
\text { main areas } \\
\text { of } \\
\text { functioning } \\
\text { (severity of } \\
\text { symptom } \\
\text { presentation; } \\
\text { social } \\
\text { adjustment; } \\
\text { global } \\
\text { assessment } \\
\text { of } \\
\text { functioning). }\end{array}$ & None specified & $\begin{array}{l}\text { Significant predictors of medium term outcome in a cluster B } \\
\text { PD sample after } 24 \text { months follow up: } \\
\text { Younger Age } \\
\text { Higher Global assessment Scale intake scores } \\
\text { Longer length of treatment } \\
\text { Absence of self mutilation } \\
\text { Avoidant PDs } \\
\text { Self harming patients allocated to the 'step down' program } \\
\text { had higher rates of improvement compared with patients } \\
\text { allocated to the LT inpatient model. }\end{array}$ \\
\hline 14. & $\begin{array}{c}\text { Comtoi } \\
\mathrm{s}\end{array}$ & 2002 & $\begin{array}{l}\text { Psychiat } \\
\text { ric }\end{array}$ & $\mathrm{N} / \mathrm{A}$ & $\mathrm{N} / \mathrm{A}$ & $\begin{array}{l}\text { Peer-reviewed } \\
\text { journals were }\end{array}$ & $\begin{array}{l}\text { Systemati } \\
\text { c review }\end{array}$ & $\begin{array}{l}\text { Treatments } \\
\text { demonstrate }\end{array}$ & $\begin{array}{l}\text { Few efficacy trials } \\
\text { are conducted. }\end{array}$ & $\begin{array}{l}\text { The author suggests eight practical steps, based on the } \\
\text { literature and established health services strategies, for }\end{array}$ \\
\hline
\end{tabular}




\begin{tabular}{|c|c|c|c|c|c|c|c|c|c|c|}
\hline & & & Services & & & $\begin{array}{c}\text { searched } \\
\text { by using MEDLINE } \\
\text { and PsycINFO } \\
\text { from } 1970 \text { to } 2001 . \\
\text { Only experimental } \\
\text { and quasi- } \\
\text { experimental } \\
\text { controlled } \\
\text { trials of treatment } \\
\text { for Para suicidal } \\
\text { individuals were } \\
\text { selected for review. } \\
\text { Presentation of the } \\
\text { results focuses on } \\
\text { health services } \\
\text { planning issues to } \\
\text { reduce the } \\
\text { prevalence of } \\
\text { parasuicide }\end{array}$ & & $\begin{array}{l}\text { d in } \\
\text { randomized } \\
\text { trials to } \\
\text { reduce } \\
\text { repetition of } \\
\text { parasuicide }\end{array}$ & & $\begin{array}{l}\text { improving services } \\
\text { to parasuicidal individuals. These steps are establishing } \\
\text { case registries, } \\
\text { evaluating the quality of care for parasuicidal persons, } \\
\text { evaluating training in empirically supported treatments for } \\
\text { parasuicide, ensuring fidelity to treatment models, evaluating } \\
\text { treatment outcomes, identifying local programs for } \\
\text { evaluation, providing infrastructural supports to treating } \\
\text { clinicians, and implementing quality improvement projects. }\end{array}$ \\
\hline 15. & $\begin{array}{c}\text { Congd } \\
\text { on \& } \\
\text { Clark }\end{array}$ & 2005 & $\begin{array}{l}\text { Public } \\
\text { Health }\end{array}$ & $\begin{array}{l}\text { Male \& } \\
\text { Female }\end{array}$ & 467 & $\begin{array}{c}\text { all patients had } \\
\text { access to routine } \\
\text { care while patients } \\
\text { in the } \\
\text { intervention group } \\
\text { were offered an } \\
\text { additional } \\
\text { treatment package } \\
\text { comprising a } \\
\text { psychosocial } \\
\text { assessment, a } \\
\text { negotiated care } \\
\text { plan and direct } \\
\text { access to a case } \\
\text { manager. }\end{array}$ & $\mathrm{RCT}$ & $\begin{array}{l}\text { The main } \\
\text { outcome } \\
\text { measure } \\
\text { was binary, } \\
\text { re- } \\
\text { attendance } \\
\text { or not at an } \\
\text { accident and } \\
\text { emergency } \\
\text { (A\&E) } \\
\text { department } \\
\text { within } 12 \\
\text { months of } \\
\text { the index } \\
\text { event. }\end{array}$ & $\begin{array}{c}\text { One problem with } \\
\text { the study was the } \\
\text { low } \\
\text { re-attendance rate } \\
\text { (averaging 10\%). } \\
\text { This, } \\
\text { together with the } \\
\text { fact that some of } \\
\text { those } \\
\text { assigned to } \\
\text { treatment refused } \\
\text { it, reduced the } \\
\text { power of the trial to } \\
\text { detect a significant } \\
\text { effect. }\end{array}$ & \\
\hline 16. & $\begin{array}{l}\text { Corcor } \\
\text { an et al }\end{array}$ & 2007 & $\begin{array}{l}\text { Journal } \\
\text { of } \\
\text { Commun } \\
\text { ity \& } \\
\text { Applied } \\
\text { Social } \\
\text { Psycholo }\end{array}$ & Female & 7 & $\begin{array}{l}\text { Recruited from } \\
\text { existing self-injury } \\
\quad \text { groups } \\
\text { Aged between } 21 \text { - } \\
44 \text { years }(M=36)\end{array}$ & $\begin{array}{l}\text { Semi- } \\
\text { structured } \\
\text { interviews } \\
\text { to } \\
\text { investigate } \\
\text { the role of } \\
\text { self-injury }\end{array}$ & & $\begin{array}{l}\text { Small sample size } \\
\text { and were similar } \\
\text { cases. This } \\
\text { resulted in a lack } \\
\text { of information to } \\
\text { challenge or enrich } \\
\text { theories. }\end{array}$ & $\begin{array}{l}\text { Recommendations include an instant referral to a female- } \\
\text { support groups may empower the women, as they were } \\
\text { generally valued by the female service users. } \\
\text { Sharing self-injury stories with those who may 'understand' } \\
\text { may reduce the associated effects that it has on women, } \\
\text { such as secrecy, isolation, shame, guilt and possibly the }\end{array}$ \\
\hline
\end{tabular}




\begin{tabular}{|c|c|c|c|c|c|c|c|c|c|c|}
\hline & & & gy & & & $\begin{array}{l}\text { All had current } \\
\text { contact with } \\
\text { professional } \\
\text { services regarding } \\
\text { self-injury and/or } \\
\text { associated } \\
\text { difficulties. }\end{array}$ & $\begin{array}{l}\text { support } \\
\text { groups in } \\
\text { women's } \\
\text { managem } \\
\text { ent of self- } \\
\quad \text { injury }\end{array}$ & & & perceived need to self-injure. \\
\hline 17. & $\begin{array}{l}\text { Crawfo } \\
\text { rd et al }\end{array}$ & 2007 & $\begin{array}{l}\text { British } \\
\text { Journal } \\
\text { of } \\
\text { Psychiat } \\
\text { ry }\end{array}$ & $\mathrm{N} / \mathrm{A}$ & $\begin{array}{l}3918 \\
(18 \\
\text { studie } \\
\text { s) }\end{array}$ & $\begin{array}{l}\text { Studies were } \\
\text { eligible for } \\
\text { inclusion in the } \\
\text { review if they were } \\
\text { randomized } \\
\text { controlled } \\
\text { trials; involved } \\
\text { patients who had } \\
\text { harmed } \\
\text { themselves in the } \\
\text { period prior to } \\
\text { entry into } \\
\text { the trial; and } \\
\text { compared } \\
\text { additional or en- } \\
\text { the trial; and } \\
\text { compared } \\
\text { additional or } \\
\text { enhanced } \\
\text { intervention with a } \\
\text { form of control } \\
\text { or standard care. }\end{array}$ & $\begin{array}{l}\text { Systemati } \\
\text { c review } \\
\text { and Meta } \\
\text { analysis of } \\
\text { RCT } \\
\text { interventio } \\
\text { ns }\end{array}$ & $\begin{array}{l}\text { Psychosocia } \\
\text { I treatment } \\
\text { interventions } \\
\text { had an } \\
\text { impact on } \\
\text { the } \\
\text { likelihood } \\
\text { of suicide }\end{array}$ & & $\begin{array}{l}\text { Individual randomized trials of psychosocial treatments have } \\
\text { demonstrated } \\
\text { statistically statistically significant reductions in the } \\
\text { significant reductions in the } \\
\text { likelihood of repetition of non-fatal self harm, but such } \\
\text { findings do not necessarily mean that these treatments } \\
\text { would reduce the likelihood of subsequent suicide. }\end{array}$ \\
\hline 18. & $\begin{array}{l}\text { Cremin } \\
\text { et al }\end{array}$ & 1995 & $\begin{array}{l}\text { Journal } \\
\text { of } \\
\text { Psychiat } \\
\text { ric and } \\
\text { Mental } \\
\text { Health } \\
\text { Nursing }\end{array}$ & $\begin{array}{l}\text { Not } \\
\text { stated }\end{array}$ & 4 & $\begin{array}{l}\text { All persistent users } \\
\text { of typical in-patient } \\
\text { psychiatric care, } \\
\text { with a history of } \\
\text { repeated self- } \\
\text { harm. } \\
\text { Diagnosed with } \\
\text { Personality } \\
\text { disorders }\end{array}$ & $\begin{array}{l}\text { Quantitativ } \\
\qquad \begin{array}{l}\text { Repeated } \\
\text { measures }\end{array} \\
4 \text { case } \\
\text { studies } \\
\text { Data } \\
\text { collection }\end{array}$ & $\begin{array}{l}\text { Reduction in } \\
\text { self harm } \\
\text { and } \\
\text { challenging } \\
\text { behaviors } \\
\text { towards } \\
\text { staff. } \\
\text { Ego } \\
\text { competency } \\
\text { Scale }\end{array}$ & $\begin{array}{l}\text { Took a lot of staff } \\
\text { energy. } \\
\text { Time consuming. } \\
3 \text { week data } \\
\text { collection period } \\
\text { was too short to } \\
\text { have any impact, } \\
\text { and only offered a } \\
\text { snapshot. }\end{array}$ & $\begin{array}{l}\text { Patients with sever personality disorder who self harm pose } \\
\text { a major challenge to staff and successful treatment. } \\
\text { Identification of the challenges and risks that the patient } \\
\text { posed through a 'pre-admission assessment interview' } \\
\text { prepared the staff for future incidents with this patient, } \\
\text { resulting in improved staff responses and a reduction in self } \\
\text { harm. } \\
\text { There were no sudden changes or reduction in self harm } \\
\text { following the } 3 \text { week period. }\end{array}$ \\
\hline
\end{tabular}




\begin{tabular}{|c|c|c|c|c|c|c|c|c|c|c|}
\hline & & & & & & & $\begin{array}{c}\text { enabled } \\
\text { measures } \\
\text { of key IV's } \\
\text { proposed } \\
\text { to reduce } \\
\text { self harm. } \\
\\
\text { Psychody } \\
\text { namic } \\
\text { perspectiv } \\
\text { e to } \\
\text { treatment. }\end{array}$ & $\begin{array}{c}\text { (suicide } \\
\text { intent; self- } \\
\text { harm } \\
\text { lethality; } \\
\text { hopelessnes } \\
\text { s and } \\
\text { depression). }\end{array}$ & & $\begin{array}{l}\text { Patient's satisfaction with life was a result due to the nurses } \\
\text { carrying effective responsibility and showing anxiety for the } \\
\text { patient. }\end{array}$ \\
\hline 19. & $\begin{array}{c}\text { Evans } \\
\text { et al }\end{array}$ & 1999 & $\begin{array}{l}\text { Psycholo } \\
\text { gical } \\
\text { Medicine }\end{array}$ & $\begin{array}{l}\text { Male \& } \\
\text { Female }\end{array}$ & 34 & $\begin{array}{c}\text { Aged between 16- } \\
50 \\
\text { Had suffered an } \\
\text { episode of } \\
\text { deliberate self- } \\
\text { harm } \\
\text { All had personality } \\
\text { disturbances } \\
\text { Exclusion criteria } \\
\text { included alcohol } \\
\text { and drug } \\
\text { dependence and } \\
\text { those diagnosed } \\
\text { with schizophrenia. }\end{array}$ & $\begin{array}{l}\text { RCT } \\
\text { Patients } \\
\text { were } \\
\text { allocated } \\
\text { to either } \\
\text { the } \\
\text { experimen } \\
\text { tal group, } \\
\text { the } \\
\text { manual } \\
\text { assisted } \\
\text { cognitive } \\
\text { behavior } \\
\text { therapy } \\
\text { group } \\
\text { (MACT) or } \\
\text { the } \\
\text { treatment } \\
\text { as usual } \\
\text { group } \\
\text { (TAU). } \\
\text { Pre and } \\
\text { post } \\
\text { treatment } \\
\text { effectivene } \\
\text { ss }\end{array}$ & $\begin{array}{l}\text { The amount } \\
\text { of time to the } \\
\text { next Para } \\
\text { suicidal act. } \\
\text { Rates of } \\
\text { acts per } \\
\text { month, } \\
\text { depressive } \\
\text { and anxiety } \\
\text { symptoms, } \\
\text { social } \\
\text { functions } \\
\text { and cost of } \\
\text { care were } \\
\text { secondary } \\
\text { outcome } \\
\text { measures. }\end{array}$ & Small sample size & $\begin{array}{l}\text { The treatment had a modest effect } \\
\text { Intervention may be effective in reducing the number and } \\
\text { frequency of self-harm episodes with simultaneous reduction } \\
\text { in depressive symptoms. } \\
\text { The efficacy of the treatment is probably best measured by } \\
\text { the rate of suicidal acts, rather than the amount time to } \\
\text { prepare to repeat. }\end{array}$ \\
\hline
\end{tabular}




\begin{tabular}{|c|c|c|c|c|c|c|c|c|c|c|}
\hline 20. & $\begin{array}{l}\text { Evans } \\
\text { et al }\end{array}$ & 1999 & $\begin{array}{l}\text { British } \\
\text { Journal } \\
\text { of } \\
\text { Psychiat } \\
\text { ry }\end{array}$ & $\begin{array}{l}\text { Male \& } \\
\text { Female }\end{array}$ & 827 & $\begin{array}{l}\text { Those recruited } \\
\text { represent } 64 \% \text { of } \\
\text { the total number of } \\
\text { patients admitted } \\
\text { to the hospital } \\
\text { wards, but only this } \\
\text { amount fitted the } \\
\text { inclusion criteria. }\end{array}$ & $\begin{array}{c}\text { RCT } \\
\text { To } \\
\text { investigate } \\
\text { the effect } \\
\text { on offering } \\
\text { emergenc } \\
y \\
\text { telephone } \\
\text { support in } \\
\text { a group of } \\
\text { hospital } \\
\text { admitted } \\
\text { DSH } \\
\text { patients. }\end{array}$ & $\begin{array}{l}\text { DSH } \\
\text { repetition } \\
\text { within } 6 \\
\text { months }\end{array}$ & $\begin{array}{l}\text { Health service } \\
\text { information was } \\
\text { used to define } \\
\text { repetition of DSH, } \\
\text { this will } \\
\text { underestimate } \\
\text { repetition on } 3 \\
\text { accounts. } \\
\\
\text { The green card did } \\
\text { not offer overnight } \\
\text { admission to a } \\
\text { psychiatric hospital } \\
\text { which may have } \\
\text { reduced its } \\
\text { potential efficacy. }\end{array}$ & $\begin{array}{l}\text { * Repetition will be underestimated due to some patients } \\
\text { admitted to other hospitals than the three identified for this } \\
\text { study; services may not identify repeat acts and finally self- } \\
\text { laceration is hard to identify. } \\
\text { Green card and crisis telephone intervention did not result in } \\
\text { a reduction of DSH }\end{array}$ \\
\hline 21. & $\begin{array}{l}\text { Evans } \\
\text { et al }\end{array}$ & 2005 & $\begin{array}{l}\text { British } \\
\text { Journal } \\
\text { of } \\
\text { Psychiat } \\
\text { ry }\end{array}$ & No info & $\begin{array}{l}827 \\
417 \\
\text { Exp } \\
\text { grp } \\
410 \\
\text { TAU } \\
\text { ctrl }\end{array}$ & & $\begin{array}{c}\text { RCT } \\
\text { TAU } \\
\text { Vs } \\
\text { TAU + } \\
\text { Crisis card }\end{array}$ & $\begin{array}{l}12 \mathrm{mth} \\
\text { repition of } \\
\mathrm{SH}\end{array}$ & $\begin{array}{l}\text { Sample not large } \\
\text { enough to exclude } \\
\text { a clinically } \\
\text { important effect in } \\
\text { those with } 1^{\text {st }} \text { time } \\
\quad \text { presentation. } \\
\text { Question about } \\
\text { whether telephone } \\
\text { contact evokes } \\
\text { rejection }\end{array}$ & $\begin{array}{l}\text { ** "Many trials have been too small to identify clinically } \\
\text { important effects" ( } \mathrm{p} .186) \\
\text { Those found to use the card were assessed as at greater } \\
\text { risk. Did the cards therefore prevent suicide or more serious } \\
\mathrm{SH} \text {, although didn't stop it all together? } \\
\text { Case studies or qualitative enquiry would answer the } \\
\text { question above and the one about rejection. }\end{array}$ \\
\hline 22. & $\begin{array}{l}\text { Glenno } \\
\mathrm{n} \text { et al }\end{array}$ & 2008 & $\begin{array}{l}\text { Internati } \\
\text { onal } \\
\text { Journal } \\
\text { of } \\
\text { Mental }\end{array}$ & $\begin{array}{l}\text { Male \& } \\
\text { Female }\end{array}$ & & $\begin{array}{l}\text { Individuals who } \\
\text { present at } \\
\text { emergency } \\
\text { departments who } \\
\text { have DSH }\end{array}$ & $\begin{array}{c}\text { Quantitativ } \\
\mathrm{e}\end{array}$ & $\begin{array}{l}\text { Mood } \\
\text { assessment } \\
\text { over three } \\
\text { sessions } \\
\text { and followed }\end{array}$ & & $\begin{array}{l}\text { Mental health services can offer a clinical pathway for DSH } \\
\text { at emergency departments. } \\
\text { Self harm reduction and service user satisfaction with mental } \\
\text { health services }\end{array}$ \\
\hline
\end{tabular}




\begin{tabular}{|c|c|c|c|c|c|c|c|c|c|c|}
\hline & & & $\begin{array}{l}\text { Health } \\
\text { Nursing }\end{array}$ & & & & & $\begin{array}{l}\text { up after } \\
\text { three and six } \\
\text { months. }\end{array}$ & & $\begin{array}{l}\text { Main focuses of the intervention included review progress in } \\
\text { problem areas, develop interventions, plans for future } \\
\text { treatment and care plan in collaboration with the patient and } \\
\text { their GP. }\end{array}$ \\
\hline 23. & $\begin{array}{l}\text { Gratz } \\
\text { et al }\end{array}$ & 2006 & $\begin{array}{l}\text { Behavior } \\
\text { Therapy }\end{array}$ & Female & 22 & $\begin{array}{c}\text { Inclusion criteria: } \\
\text { Meeting five or } \\
\text { more criteria for } \\
\text { BPD } \\
\text { History of DSH } \\
\text { Has an individual } \\
\text { therapist } \\
\text { Between 18-60 } \\
\text { years }\end{array}$ & $\begin{array}{l}\text { RCT } \\
\text { Randomly } \\
\text { assigned } \\
\text { to either } \\
\text { group } \\
\text { treatment } \\
\text { plus } \\
\text { treatment } \\
\text { as usual } \\
\text { (TAU) or } \\
\text { TAU } \\
\text { waitlist } \\
\text { condition. }\end{array}$ & $\begin{array}{l}\text { The use of } \\
\text { DSH } \\
\text { Difficulties in } \\
\text { emotional } \\
\text { regulation } \\
\text { Rate of } \\
\text { avoidance } \\
\text { undesirable } \\
\text { feelings } \\
\text { BPD } \\
\text { Depression } \\
\text { and anxiety } \\
\text { (all scales) }\end{array}$ & $\begin{array}{l}\text { Requires } \\
\text { replication in a } \\
\text { larger scale RCT }\end{array}$ & $\begin{array}{l}\text { Group intervention had positive effects on self harm and } \\
\text { emotional dysregulation, BPD symptoms, depression, } \\
\text { anxiety and stress. }\end{array}$ \\
\hline 24. & $\begin{array}{l}\text { Gratz } \\
\text { et al }\end{array}$ & 2006 & $\begin{array}{l}\text { Behavior } \\
\text { Therapy }\end{array}$ & Female & 22 & $\begin{array}{l}\text { Independent } \\
\text { Measures } \\
\text { Randomly } \\
\text { assigned to group } \\
\text { intervention plus } \\
\text { treatment } \\
\text { condition, or the } \\
\text { condition of } \\
\text { treatment alone. }\end{array}$ & & & & \\
\hline 25. & $\begin{array}{l}\text { Gratz } \\
\text { et all }\end{array}$ & 2007 & $\begin{array}{l}\begin{array}{c}\text { Journal } \\
\text { of }\end{array} \\
\text { Clinical } \\
\text { Psycholo } \\
\text { gy: In } \\
\text { Session }\end{array}$ & $\mathrm{N} / \mathrm{A}$ & $\mathrm{N} / \mathrm{A}$ & $\begin{array}{l}\text { Individuals who } \\
\text { engage in self- } \\
\text { injury and DSH }\end{array}$ & $\begin{array}{l}\text { Reduction } \\
\text { of self- } \\
\text { injury } \\
\text { through } \\
\text { emotional } \\
\text { regulation }\end{array}$ & & $\begin{array}{l}\text { Debates over } \\
\text { emotional } \\
\text { regulation and } \\
\text { emotional } \\
\text { temperament. }\end{array}$ & $\begin{array}{l}\text { Case illustration of two treatments } \\
\text { Treating self-injury through regulation of emotions }\end{array}$ \\
\hline
\end{tabular}




\begin{tabular}{|c|c|c|c|c|c|c|c|c|c|c|}
\hline & $\begin{array}{l}\text { Gunnel } \\
\text { et al }\end{array}$ & 2004 & $\begin{array}{l}\text { Journal } \\
\text { of Public } \\
\text { Health }\end{array}$ & $\begin{array}{l}\text { Male \& } \\
\text { Female }\end{array}$ & $\begin{array}{l}31 \\
\text { hospit } \\
\text { als } \\
\\
4033 \\
\text { episod } \\
\text { es of } \\
\text { self- } \\
\text { harm }\end{array}$ & $\begin{array}{c}\text { Number of episode } \\
\text { of self harm } \\
\text { presented to } \\
\text { accident and } \\
\text { emergency at the } \\
\text { identified sites. } \\
\text { Male }(45.2 \%) \\
\text { Female }(54.8 \%) \\
\text { Male age range } \\
(18-95) \\
\text { Female age range } \\
(18-90)\end{array}$ & $\begin{array}{c}\text { Meta } \\
\text { analysis }\end{array}$ & $\begin{array}{l}\text { Patterns of } \\
\text { self harm in } \\
\text { presentation } \\
\text { to } \\
\text { emergency } \\
\text { services }\end{array}$ & $\begin{array}{l}\text { Data was collected } \\
\text { on forms will little } \\
\text { room for text to be } \\
\text { received. This } \\
\text { meant that detailed } \\
\text { information and } \\
\text { demographic on } \\
\text { each individual } \\
\text { and their } \\
\text { circumstances } \\
\text { could not be } \\
\text { collated. }\end{array}$ & $\begin{array}{l}\text { Peak times for self-harm are outside the normal working } \\
\text { hours, peaking between } 8 \mathrm{pm} \text { and } 1 \mathrm{am} \text {. } \\
\text { Self-harm episodes occurred on an average of } 2.3 \text { episodes } \\
\text { per day }\end{array}$ \\
\hline 27. & $\begin{array}{l}\text { Guthrie } \\
\text { et al }\end{array}$ & 2001 & $\begin{array}{l}\text { British } \\
\text { Medical } \\
\text { Journal }\end{array}$ & $\begin{array}{l}\text { Male \& } \\
\text { Female }\end{array}$ & 119 & $\begin{array}{l}\text { Adults who had } \\
\text { deliberately self- } \\
\text { poisoned and } \\
\text { presented to the } \\
\text { emergency } \\
\text { department of a } \\
\text { teaching hospital. } \\
\\
\text { Inclusion criteria } \\
\text { included able to } \\
\text { read and write } \\
\text { English, living } \\
\text { within the } \\
\text { catchment area of } \\
\text { the hospital, have } \\
\text { a registered GP } \\
\text { and not need } \\
\text { inpatient }\end{array}$ & RCT & $\begin{array}{l}\text { Severity of } \\
\text { treatment } 6 \\
\text { months after } \\
\text { treatment } \\
\\
\text { Six month } \\
\text { follow up } \\
\text { including } \\
\text { depressive } \\
\text { symptoms, } \\
\text { patient's } \\
\text { satisfaction } \\
\text { with } \\
\text { treatment } \\
\text { and self- } \\
\text { reported } \\
\text { attempts at } \\
\text { self-harm. }\end{array}$ & $\begin{array}{l}\text { Inclusion criteria } \\
\text { meant that } \\
\text { individuals who } \\
\text { were at a higher } \\
\text { risk of suicidal } \\
\text { behavior in the } \\
\text { future } \\
\text { were excluded }\end{array}$ & $\begin{array}{l}\text { Inpatients who poisoned themselves or have suicidal } \\
\text { ideation and self reported self harm was reduced after } \\
\text { psychological interventions. }\end{array}$ \\
\hline
\end{tabular}




\begin{tabular}{|c|c|c|c|c|c|c|c|c|c|c|}
\hline & & & & & & $\begin{array}{l}\text { psychiatric } \\
\text { treatment. }\end{array}$ & & & & \\
\hline 28. & $\begin{array}{l}\text { Guthrie } \\
\text { et al }\end{array}$ & 2003 & $\begin{array}{l}\text { Australia } \\
\mathrm{n} \text { and } \\
\text { New } \\
\text { Zealand } \\
\text { Journal } \\
\text { of } \\
\text { Psychiat } \\
\text { ry }\end{array}$ & $\begin{array}{l}\text { Male \& } \\
\text { Female }\end{array}$ & 119 & $\begin{array}{l}\text { Patients presenting } \\
\text { at accident and } \\
\text { emergency with } \\
\text { deliberate self- } \\
\text { poisoning }\end{array}$ & $\begin{array}{c}\text { RCT } \\
\text { Assigned } \\
\text { to } \\
\text { psychodyn } \\
\text { amic- } \\
\text { interperso } \\
\text { nal } \\
\text { therapy or } \\
\text { usual care }\end{array}$ & $\begin{array}{l}\text { Reduction in } \\
\text { severity of } \\
\text { suicidal } \\
\text { ideation, } \\
\text { anxiety and } \\
\text { prior history } \\
\text { of self harm }\end{array}$ & & $\begin{array}{l}\text { Four sessions of psychodynamic-interpersonal therapy for } \\
\text { deliberate self-poisoning is effective in reducing suicidal } \\
\text { ideation in less severe cases with no previous history of self- } \\
\text { harm. } \\
\text { Repetition of self-harm is the main predictor variable. } \\
\text { Age and gender was not a predictor variable }\end{array}$ \\
\hline 29. & $\begin{array}{l}\text { Hawto } \\
\mathrm{n} \text { et al }\end{array}$ & 1998 & $\begin{array}{l}\text { British } \\
\text { Medical } \\
\text { Journal }\end{array}$ & $\begin{array}{l}\text { Male \& } \\
\text { Female }\end{array}$ & 2452 & $\begin{array}{l}\text { Patients who had } \\
\text { deliberately self- } \\
\text { harmed } \\
\text { themselves shortly } \\
\text { before entry into } \\
\text { the trials with } \\
\text { information on } \\
\text { repetitive behavior }\end{array}$ & $\begin{array}{c}\text { Systemati } \\
\text { c review of } \\
\text { RCT }\end{array}$ & $\begin{array}{l}\text { Repetition of } \\
\text { self-harm }\end{array}$ & $\begin{array}{l}\text { Results show } \\
\text { considerable } \\
\text { uncertainty as to } \\
\text { whether physical } \\
\text { or psychosocial } \\
\text { treatments are } \\
\text { most effective for } \\
\text { DSH }\end{array}$ & \\
\hline 30. & $\begin{array}{l}\text { Hawto } \\
n \text { et al }\end{array}$ & 2000 & $\begin{array}{c}\text { Cochran } \\
e \\
\text { Databas } \\
e \\
\text { System } \\
\text { review }\end{array}$ & $\begin{array}{l}\text { Male \& } \\
\text { Female }\end{array}$ & & $\begin{array}{l}\text { Prior to the study } \\
\text { had engaged in } \\
\text { any form of } \\
\text { deliberate self } \\
\text { harm or self } \\
\text { poisonous } \\
\text { behavior }\end{array}$ & $\begin{array}{l}\text { RCT Meta } \\
\text { analysis }\end{array}$ & $\begin{array}{l}\text { The efficacy } \\
\text { of treatment } \\
\text { interventions } \\
\text { for DSH and } \\
\text { the rate of } \\
\text { repeated } \\
\text { self-harm } \\
\text { within a year } \\
\text { follow up } \\
\text { period. }\end{array}$ & $\begin{array}{l}\text { Some methods of } \\
\text { DSH were not } \\
\text { specified in the } \\
\text { studies }\end{array}$ & $\begin{array}{l}\text { Insufficient evidence to make firm recommendations about } \\
\text { the most effective form of treatment for patients who DSH. }\end{array}$ \\
\hline 31. & $\begin{array}{c}\text { Hawto } \\
\mathrm{n}\end{array}$ & 2000 & $\begin{array}{c}\text { Europea } \\
n \\
\text { Psychiat } \\
\text { ry }\end{array}$ & & & & $\begin{array}{l}\text { Systemati } \\
\text { c review of } \\
\text { literature }\end{array}$ & $\begin{array}{l}\text { Prevention } \\
\text { of suicidal } \\
\text { behavior in } \\
\text { DSH } \\
\text { patients }\end{array}$ & $\begin{array}{l}\text { Insufficient } \\
\text { numbers of } \\
\text { subjects in the } \\
\text { trials limit the } \\
\text { conclusions }\end{array}$ & Promising results for problem-solving therapy \\
\hline
\end{tabular}




\begin{tabular}{|c|c|c|c|c|c|c|c|c|c|c|}
\hline 32. & $\begin{array}{l}\text { Hepp } \\
\text { et al }\end{array}$ & 2004 & Crisis & $\begin{array}{l}\text { Male \& } \\
\text { Female }\end{array}$ & $\begin{array}{l}25 \\
\text { studie } \\
\text { s }\end{array}$ & $\begin{array}{l}\text { Inclusion criteria: } \\
\text { If they had recently } \\
\text { attempted suicide, } \\
\text { DSH or self- } \\
\text { poisoning }\end{array}$ & $\begin{array}{c}\text { An } \\
\text { overview } \\
\text { of } \\
\text { treatment } \\
\text { studies } \\
\text { RCT } \\
\text { Assigned } \\
\text { to a } \\
\text { psychologi } \\
\text { cal or } \\
\text { psychosoc } \\
\text { ial } \\
\text { approach }\end{array}$ & $\begin{array}{l}\text { Recurrence } \\
\text { of attempted } \\
\text { suicide, } \\
\text { suicide, DSH } \\
\text { or self- } \\
\text { poisoning }\end{array}$ & $\begin{array}{l}\text { Too small sample } \\
\text { - leads to type II } \\
\text { error and the } \\
\text { assumption that } \\
\text { there is no effect } \\
\text { when there may be } \\
\text { in a larger sample } \\
\text { size }\end{array}$ & $\begin{array}{l}\text { Although not statistically significant, a reduction in DSH was } \\
\text { found and can offer insight in future strategies for preventing } \\
\text { repeated DSH }\end{array}$ \\
\hline 33. & $\begin{array}{l}\text { Hoch } \\
\text { et al }\end{array}$ & 2006 & $\begin{array}{l}\text { Psychiat } \\
\text { ric } \\
\text { Services }\end{array}$ & $\begin{array}{l}\text { Male } \\
(2) \\
\text { Female } \\
(25)\end{array}$ & 27 & $\begin{array}{c}\text { Diagnosed with } \\
\text { BPD }\end{array}$ & & $\begin{array}{l}\text { Incidents of } \\
\text { self-harm } \\
\text { Hours of } \\
\text { seclusion } \\
\text { Restraint } \\
\text { Number of } \\
\text { nursing } \\
\text { observations } \\
\text { Number of } \\
\text { hospital } \\
\text { admissions } \\
\text { Inpatient } \\
\text { length of } \\
\text { stay }\end{array}$ & $\begin{array}{l}\text { Small sample } \\
\text { Retrospective } \\
\text { design } \\
\text { Lack of } \\
\text { randomization }\end{array}$ & $\begin{array}{l}\text { Relationship management therapy reduced the frequency of } \\
\text { restraints and seclusion. } \\
\text { Suggestion of a reduction in suicidal behavior }\end{array}$ \\
\hline 34. & $\begin{array}{l}\text { Kapur } \\
\text { et al }\end{array}$ & 2008 & $\begin{array}{l}\text { J. of } \\
\text { Affective } \\
\text { Disorder } \\
\text { s }\end{array}$ & $\begin{array}{c}\text { Female } \\
(4186) \\
\text { Male } \\
(3148)\end{array}$ & 7334 & $\begin{array}{l}\text { Multi-site A\&E } \\
\text { admissions }\end{array}$ & $\begin{array}{l}\text { Audit of } \\
\text { psychosoc } \\
\text { ial } \\
\text { assessme } \\
\text { nt after SH }\end{array}$ & $\begin{array}{c}\text { Repetition of } \\
\text { SH }\end{array}$ & $\begin{array}{l}\text { Variability of } \\
\text { assessment - how } \\
\text { and when its } \\
\text { carried out }\end{array}$ & $\begin{array}{l}\text { Conclude that psychosocial assessments may be protective } \\
\text { against SH but this is far from definite. - PAR to ask about } \\
\text { experience of assessment and whether there is any effect. } \\
\text { Given the importance of listening and empathy is this the } \\
\text { effect? }\end{array}$ \\
\hline
\end{tabular}




\begin{tabular}{|c|c|c|c|c|c|c|c|c|c|c|}
\hline 35. & Kapur & 2005 & $\begin{array}{l}\text { British } \\
\text { Journal } \\
\text { of } \\
\text { Psychiat } \\
\text { ry }\end{array}$ & $\mathrm{N} / \mathrm{A}$ & $\mathrm{N} / \mathrm{A}$ & $\mathrm{N} / \mathrm{A}$ & $\mathrm{N} / \mathrm{A}$ & $\mathrm{N} / \mathrm{A}$ & $\mathrm{N} / \mathrm{A}$ & $\begin{array}{l}\text { Review of policy and research literature. } \\
\text { Recommends repetition of repeat presentation shouldn't be } \\
\text { the only outcome measure but also quality of life and user } \\
\text { satisfaction. } \\
\text { Also recommends alternative methods of investigation such } \\
\text { as qualitative and cohort studies. }\end{array}$ \\
\hline 36. & $\begin{array}{l}\text { Katz \& } \\
\text { Levend } \\
\text { usky }\end{array}$ & 1990 & $\begin{array}{l}\text { Bulletin } \\
\text { of the } \\
\text { Menning } \\
\text { er Clinic }\end{array}$ & Female & 3 & $\begin{array}{l}\text { All diagnosed BPD } \\
\text { All in patient at } \\
\text { single site }\end{array}$ & $\begin{array}{l}\text { Case } \\
\text { studies }\end{array}$ & None & None & $\begin{array}{l}\text { "patient as collaborator whilst treater uses expertise to help } \\
\text { the patient who is at that point" - highlights the need for a } \\
\text { collaborative approach. }\end{array}$ \\
\hline 37. & $\begin{array}{l}\text { Kelly et } \\
\text { al. }\end{array}$ & 2008 & $\begin{array}{l}\text { BMC } \\
\text { Psychiat } \\
\text { ry }\end{array}$ & $\mathrm{N} / \mathrm{A}$ & $\mathrm{N} / \mathrm{A}$ & $\mathrm{N} / \mathrm{A}$ & $\begin{array}{l}\text { Delphi } \\
\text { process }\end{array}$ & $\mathrm{N} / \mathrm{A}$ & $\begin{array}{l}\text { The difference } \\
\text { between } \\
\text { professional } \\
\text { accepted } \\
\text { statements and } \\
\text { service user } \\
\text { accepted } \\
\text { statements }\end{array}$ & $\begin{array}{l}\text { SUs priorities were around rights to choose and receiving } \\
\text { empathic understanding. } \\
\text { Professional priorities were around emergency care and risk } \\
\text { assessment. } \\
\text { Disagreement between SUs around the carrying of } 1^{\text {st }} \text { aid } \\
\text { kits and whether interventions can, over time, remove the } \\
\text { need to SH. } \\
\text { *SUs all agreed that stopping SH is not and should not be a } \\
\text { treatment target. }\end{array}$ \\
\hline 38. & $\begin{array}{l}\text { Klonsk } \\
\text { y \& } \\
\text { Muehle } \\
\text { nkamp }\end{array}$ & 2007 & $\begin{array}{l}\text { J. } \\
\text { Clinical } \\
\text { Psycholo } \\
\text { gy: In } \\
\text { Session }\end{array}$ & $\mathrm{N} / \mathrm{A}$ & $\mathrm{N} / \mathrm{A}$ & N/A & $\mathrm{N} / \mathrm{A}$ & $\mathrm{N} / \mathrm{A}$ & N/A & $\begin{array}{l}\text { The paper is a literature review aimed at being practically } \\
\text { applied by practitioners. There is no discussion around SUI } \\
\text { or effects of poor service delivery. There is also no mention } \\
\text { of NICE clinical guidelines. }\end{array}$ \\
\hline 39. & $\begin{array}{l}\text { Klonsk } \\
\text { y \& } \\
\text { Glenn }\end{array}$ & 2008 & $\begin{array}{l}\text { Behavio } \\
\text { ural \& } \\
\text { Cognitiv } \\
\text { e } \\
\text { Psycholo } \\
\text { gy }\end{array}$ & $\begin{array}{l}\text { Female } \\
\text { (30) } \\
\text { Male (9) }\end{array}$ & 39 & $\begin{array}{l}\text { College students } \\
\text { screened for NS } \\
\text { DSH. } \\
\text { All SH by cutting, } \\
\text { although did report } \\
\text { other methods }\end{array}$ & $\begin{array}{l}\text { Structured } \\
\text { interview }\end{array}$ & $\begin{array}{l}\text { N/A } \\
\text { Exploring } \\
\text { usefulness } \\
\text { of strategies } \\
\text { to resist urge } \\
\text { to SH }\end{array}$ & $\begin{array}{l}\text { 1. College } \\
\text { students } \\
\text { 2. No access to } \\
\text { psychopathology } \\
\text { 3. Valid \& reliable } \\
\text { psychometrics nor } \\
\text { used } \\
\text { 4. Use of diary } \\
\text { rather than }\end{array}$ & $\begin{array}{l}\text { 3. Wouldn't need to validate tools if just explored coping } \\
\text { strategies in a less structured way. PAR to draw up the } \\
\text { original list. } \\
\text { Explore why most useful strategies aren't the most } \\
\text { commonly used. }\end{array}$ \\
\hline
\end{tabular}




\begin{tabular}{|c|c|c|c|c|c|c|c|c|c|c|}
\hline & & & & & & & & & $\begin{array}{l}\text { retrospective } \\
\text { reporting }\end{array}$ & \\
\hline 40. & $\begin{array}{c}\text { Kool, } \\
\text { van } \\
\text { Meijel } \\
\& \\
\text { Bosma } \\
\text { n }\end{array}$ & 2009 & $\begin{array}{l}\text { Archives } \\
\text { of } \\
\text { psychiatr } \\
\text { ic } \\
\text { nursing }\end{array}$ & Female & 12 & $\begin{array}{l}\begin{array}{c}\text { Single site } \\
\text { intensive } \\
\text { psychiatric } \\
\text { treatment centre. }\end{array} \\
\text { All participants } \\
\text { have a long history } \\
\text { of SH. } \\
\text { Based in Holland }\end{array}$ & $\begin{array}{l}\text { Qual SSI } \\
\text { and } \\
\text { timeline of } \\
\text { SH }\end{array}$ & $\begin{array}{l}\text { Understandi } \\
\text { ng of the } \\
\text { process of } \\
\text { stopping SH }\end{array}$ & $\begin{array}{l}\text { Small, select group } \\
\text { of pp's all able to } \\
\text { describe the } \\
\text { recovery process }\end{array}$ & $\begin{array}{l}\text { 'Member checking' was used to validate facts and } \\
\text { interpretation of interviews. } \\
\text { Patient feeling connected to treatment providers was a key } \\
\text { factor in cessation of SH. If clinicians are doing the } \\
\text { research, as is often the case, could PAR aid in the } \\
\text { connection with another person who has similar experience } \\
\text { and thus provide a positive effect from the research process. } \\
\text { PAR increasing validation of identity and so possible positive } \\
\text { impact upon self-esteem. }\end{array}$ \\
\hline 41. & $\begin{array}{l}\text { Kriplan } \\
\text { i, Nag, } \\
\text { Nag, \& } \\
\text { Gash }\end{array}$ & 2010 & $\begin{array}{c}\text { Emergen } \\
\text { cy } \\
\text { Medicine } \\
\text { Journal }\end{array}$ & $\begin{array}{l}\text { Female } \\
(121) \\
\text { Male } \\
(107)\end{array}$ & 221 & $\begin{array}{l}\text { All presenting at } \\
\text { A\&E following } \\
\text { episode of } \mathrm{SH}\end{array}$ & $\begin{array}{l}\text { Report on } \\
\text { quantitativ } \\
\text { e info }\end{array}$ & $\begin{array}{l}\text { A\&E waiting } \\
\text { time }\end{array}$ & None & $\begin{array}{l}\text { Claims excellent patient and staff feedback - none of this } \\
\text { reported though. } \\
\text { PAR to explore experience of treatment, especially given } \\
\text { previous concerns raised at A\&E (Pembroke, 1994) } \\
\text { Asserts admission allows for 'time out' - is this the } \\
\text { experience of SUs? }\end{array}$ \\
\hline 42. & $\begin{array}{l}\text { Lampr } \\
\text { echt et } \\
\text { al. }\end{array}$ & 2007 & $\begin{array}{l}\text { J. } \\
\text { Psychiat } \\
\text { ric and } \\
\text { MH } \\
\text { nursing }\end{array}$ & $\begin{array}{l}\text { Female } \\
\quad(15) \\
\text { Male (17) }\end{array}$ & 32 & $\begin{array}{c}\text { No info - See } \\
\text { Wiseman } 2003\end{array}$ & $\begin{array}{c}\text { SFBT vs } \\
\text { TAU }\end{array}$ & $\begin{array}{l}\text { Repetition of } \\
\text { SH after } 1 \\
\text { year }\end{array}$ & $\begin{array}{l}\text { Can't draw } \\
\text { conclusion from } \\
\text { pilot study }\end{array}$ & $\begin{array}{l}\text { Suggests SFBT has shifted philosophy towards 'the patient } \\
\text { as expert on themselves'. If this is the case then why not } \\
\text { ask if it was useful? }\end{array}$ \\
\hline 43. & $\begin{array}{l}\text { Levy, } \\
\text { Yeoma } \\
\text { ns, \& } \\
\text { Diamo } \\
\text { nd }\end{array}$ & 2007 & $\begin{array}{l}\text { J. Clin. } \\
\text { Psycholo } \\
\text { gy }\end{array}$ & Female & $\begin{array}{l}1 \\
\text { single } \\
\text { case } \\
\text { study }\end{array}$ & BPD & $\begin{array}{l}\text { Case } \\
\text { study }\end{array}$ & $\begin{array}{l}\text { Case study } \\
\text { of TFP }\end{array}$ & None & No account of service users experience of therapy? \\
\hline
\end{tabular}




\begin{tabular}{|c|c|c|c|c|c|c|c|c|c|c|}
\hline 44. & $\begin{array}{l}\text { Lineha } \\
\mathrm{n} \text { et al }\end{array}$ & 1991 & $\begin{array}{l}\text { Archives } \\
\text { of } \\
\text { General } \\
\text { Psychiat } \\
\text { ry }\end{array}$ & Female & $\begin{array}{l}22 \text { in } \\
\text { DBT } \\
22 \text { in } \\
\text { Ctrl }\end{array}$ & All diagnosed BPD & $\begin{array}{l}\text { RCT } \\
\text { DBT vs } \\
\text { TAU }\end{array}$ & $\begin{array}{l}\text { Parasuicide } \\
\text { Therapy } \\
\text { maintenance } \\
\text { Inpatient } \\
\text { admission }\end{array}$ & $\begin{array}{l}\text { Unable to } \\
\text { determine what } \\
\text { causes the } \\
\text { treatment effect } \\
\text { Unclear why the } \\
\text { low attrition }\end{array}$ & $\begin{array}{l}\text { Ask why? } \\
19 \text { (almost } 1 / 3 \text { of original referrals) potential participants } \\
\text { dropped out before intervention began - why? }\end{array}$ \\
\hline 45. & $\begin{array}{c}\text { Low et } \\
\text { al }\end{array}$ & 2001 & $\begin{array}{l}\text { Clinical } \\
\text { Psycholo } \\
\text { gy and } \\
\text { Psychot } \\
\text { herapy }\end{array}$ & Female & 15 & BPD in Rampton & $\begin{array}{l}\text { A-B } \\
\text { design } \\
\text { Individual } \\
\text { case } \\
\text { studies } \\
\text { presented }\end{array}$ & $\begin{array}{l}\text { Numerous } \\
\text { including } \\
\text { repetition of } \\
\text { SH }\end{array}$ & None & $\begin{array}{l}\text { Ms A - Therapeutic relationship and validation of her } \\
\text { experiences were important in treatment. } \\
\text { Ms } L-\text { masked her feelings behind a smile when presenting } \\
\text { for first aid following SH, this resulted in staff viewing her } \\
\text { behaviour as manipulative and attention seeking. } \\
\text { Introducing opportunities to talk to staff about how she was } \\
\text { really feeling addressed this issue. } \\
\text { All three case studies presented show what aspects of } \\
\text { intervention were useful for the individual. It is unclear what } \\
\text { input the patient had in each of these formulations and } \\
\text { agreement 'member checking' would add validity. }\end{array}$ \\
\hline 46. & $\begin{array}{l}\text { Malon } \\
\quad \& \\
\text { Beradi }\end{array}$ & 1987 & $\begin{array}{l}\text { America } \\
\mathrm{n} \mathrm{J} \text {. of } \\
\text { Psychot } \\
\text { herapy }\end{array}$ & Female & 3 & Case vignettes & & & None & $\begin{array}{l}\text { **Nelson \& Grunebaum (1971) reported equal patient-doctor } \\
\text { relationship as being the most important aspect of treatment. } \\
\text { This doesn't seem to have been reflected in studies after this } \\
\text { date. } \\
\text { Hypnotic techniques used were individual to the client. }\end{array}$ \\
\hline 47. & $\begin{array}{c}\text { Marriot } \\
\text { t et al }\end{array}$ & 2003 & $\begin{array}{l}\text { Internati } \\
\text { onal J. of } \\
\text { Geriatric } \\
\text { Psychiat } \\
\text { ry }\end{array}$ & $\begin{array}{l}\text { Female } \\
(84) \\
\text { Male (57) }\end{array}$ & 141 & $\begin{array}{l}\text { All over } 55 \\
\text { presenting to } A \& E \\
\text { in Leeds over a } 12 \\
\text { month period. }\end{array}$ & $\begin{array}{l}\text { Audit of } \\
\text { A\&E } \\
\text { records }\end{array}$ & $\begin{array}{l}\text { Whether } \\
\text { psychosocial } \\
\text { assessment } \\
\text { was given } \\
\text { Whether }\end{array}$ & None & $?$ \\
\hline
\end{tabular}




\begin{tabular}{|c|c|c|c|c|c|c|c|c|c|c|}
\hline & & & & & & & & $\begin{array}{l}\text { person was } \\
\text { admitted }\end{array}$ & & \\
\hline 48. & $\begin{array}{l}\text { McElro } \\
\text { y \& } \\
\text { Shepp } \\
\text { ard }\end{array}$ & 1999 & $\begin{array}{l}\text { J. of } \\
\text { Clinical } \\
\text { Nursing }\end{array}$ & $\begin{array}{c}\text { All } \\
\text { medical } \\
\text { staff, } \\
\text { gender } \\
\text { not } \\
\text { disclosed }\end{array}$ & 22 & $\mathrm{~N} / \mathrm{A}$ & $\begin{array}{l}\text { Action } \\
\text { Research } \\
\text { Structured } \\
\text { interviews } \\
\text { and } \\
\text { vignettes }\end{array}$ & $\begin{array}{c}\text { Attitudes } \\
\text { and } \\
\text { knowledge } \\
\text { towards SH } \\
\text { Policies and } \\
\text { procedures } \\
\text { for SH } \\
\text { managemen } \\
\text { t }\end{array}$ & None & $\begin{array}{l}\text { Confounds SH and suicide } \\
\text { There is little reporting on the findings of the research phase } \\
\text { of the AR cycle } \\
\text { There is little critical review of the action stage. } \\
\text { No use of SUs in the process. } \\
\text { Attitudes towards SH \& suicide were mixed and a result of } \\
\text { personal history rather than background. No attempt to } \\
\text { address attitudes though through the AR. }\end{array}$ \\
\hline 49. & $\begin{array}{l}\text { McMai } \\
n \text { et al }\end{array}$ & 2009 & $\begin{array}{c}\text { America } \\
n \mathrm{~J} \text { of } \\
\text { Psychiat } \\
\text { ry }\end{array}$ & $\begin{array}{c}\text { Female } \\
(155) \\
\text { Male (25) }\end{array}$ & 180 & All diagnosed BPD & $\begin{array}{l}\text { RCT } \\
\text { DBT vs } \\
\text { General } \\
\text { Psychiatric } \\
\text { Managem } \\
\text { ent (also } \\
\text { manualise } \\
\quad \text { d) }\end{array}$ & $\begin{array}{l}\text { Frequency } \\
\text { of suicidal \& } \\
\text { NSSI }\end{array}$ & $\begin{array}{l}\text { Both interventions } \\
\text { show an effect but } \\
\text { it is unclear why } \\
\text { No control for co- } \\
\text { interventions }\end{array}$ & $\begin{array}{l}\text { Again accessing SUs subjective experience of intervention, } \\
\text { what worked and what didn't work would help understand } \\
\text { treatment effect. }\end{array}$ \\
\hline 50. & $\begin{array}{c}\text { Myriam } \\
\& \\
\text { Moffae } \\
\text { rt }\end{array}$ & 1991 & $\begin{array}{c}\text { General } \\
\text { Hospital } \\
\text { Psychiat } \\
\text { ry }\end{array}$ & $\begin{array}{c}\text { Female } \\
(184) \\
\text { Male (61) } \\
\\
208 \\
\text { entered } \\
\text { Integrate } \\
d \\
\text { Medical/P } \\
\text { sych } \\
\text { treatment } \\
\\
37 \\
\text { Sequenti } \\
\text { al } \\
\text { Medical/p } \\
\text { sych }\end{array}$ & 245 & $\begin{array}{l}\text { All presenting at } \\
\text { University Hospital } \\
\text { Ghent (single site) } \\
\text { Psychotic patients } \\
\text { excluded }\end{array}$ & $\begin{array}{l}\text { Between } \\
\text { groups } \\
\text { design } \\
\text { IT vs ST }\end{array}$ & $\begin{array}{l}\text { 1. Treatment } \\
\text { compliance } \\
\text { 2. Evolution } \\
\text { of cutaneous } \\
\text { legions } \\
3 . \\
\text { Occurrence } \\
\text { of } \\
\text { psychiatric } \\
\text { complication } \\
\text { s } \\
\text { 4. Medical } \\
\text { consumption }\end{array}$ & None & $\begin{array}{l}\text { "Neither did we have much difficulty in motivating the self- } \\
\text { mutilators to comply...because we took advantage of their } \\
\text { avidity to be the focus of medical attention" } \\
\text { "Even patients whose lesions are particularly extensive and } \\
\text { deep often do not acknowledge any pain and tolerate painful } \\
\text { diagnostic procedures or treatment without analgesia" } \\
\text { Both evidence of a less than patient focused approach. }\end{array}$ \\
\hline
\end{tabular}




\begin{tabular}{|c|c|c|c|c|c|c|c|c|c|c|}
\hline & & & & $\begin{array}{l}\text { treatment } \\
(\mathrm{TAU})\end{array}$ & & & & & & \\
\hline 51. & $\begin{array}{l}\text { Nee \& } \\
\text { Farma } \\
\quad \mathrm{n}\end{array}$ & 2005 & $\begin{array}{l}\text { Criminal } \\
\text { Beh. \& } \\
\text { M.H. }\end{array}$ & Female & 16 & $\begin{array}{c}\text { All in prison, all } \\
\text { diagnosed with } \\
\text { BPD }\end{array}$ & & $\begin{array}{c}\text { Multiple } \\
\text { including SH } \\
\text { incidents, } \\
\text { suicide } \\
\text { ideation, \& } \\
\text { impulsivity. }\end{array}$ & $\begin{array}{l}\text { Speculation about } \\
\text { why there was a } \\
\text { post treatment } \\
\text { increase in } \mathrm{SH} \text { c/f } \\
\text { during treatment }\end{array}$ & $\begin{array}{l}\text { There were qualitative measures but these aren't reported - } \\
\text { why? }\end{array}$ \\
\hline 52. & $\begin{array}{l}\text { Ryan, } \\
\text { Park, \& } \\
\text { Babidg } \\
\text { e }\end{array}$ & 1998 & $\begin{array}{l}\text { Australia } \\
\text { n Health } \\
\text { Review }\end{array}$ & $\begin{array}{l}\text { Male (28) } \\
\text { Female } \\
\text { (23) }\end{array}$ & 51 & $\begin{array}{c}\text { All referred to } \\
\text { Psychiatric Liaison } \\
\text { Team from A\&E } \\
\text { over a } 3 \text { month } \\
\text { period }\end{array}$ & $\begin{array}{l}\text { Retrospect } \\
\text { ive clinical } \\
\text { study. } \\
\text { Data } \\
\text { collected } \\
\text { on suicide } \\
\text { attempts }\end{array}$ & N/A & $\begin{array}{c}\text { No inclusion of } \\
\text { those completing } \\
\text { suicide or rapid } \\
\text { discharge from } \\
\text { A\&E }\end{array}$ & $\begin{array}{l}\text { N/A But would PAR add validity to the model if it was } \\
\text { presented to SUs? }\end{array}$ \\
\hline 53. & Shaw & 2006 & $\begin{array}{l}\text { Women } \\
\& \\
\text { Therapy }\end{array}$ & Female & 6 & $\begin{array}{l}\text { College students } \\
\text { with short duration } \\
\text { of } \mathrm{SH} \text { (max } 50 \\
\text { incidents). All } \\
\text { participants not } \\
\text { currently }\end{array}$ & $\begin{array}{c}3 x \\
\text { interviews } \\
\text { 1. Life } \\
\text { context } \\
\text { 2. Details } \\
\text { of use of } \\
\text { SH } \\
3 . \\
\text { Meaning \& } \\
\text { impact of } \\
\text { SH }\end{array}$ & $\begin{array}{l}\mathrm{N} / \mathrm{A} \\
\text { Exploring } \\
\text { reasons for } \\
\text { desistance }\end{array}$ & None & $\begin{array}{l}\text { "All women spoke of taking control of their lives as essential } \\
\text { in their journey toward stopping" (p.162) } \\
\text { "key features women found useful in stopping SI included } \\
\text { empathic relationship with a professional who sees strengths } \\
\text { beyond diagnostic labels" (p.167) } \\
\text { Some preferred a directive approach like DBT whilst others } \\
\text { a more client centered approach. } \\
\text { *Women's sensitivity to common unease with SI was evident } \\
\text { - If interviewed by a woman with a history SH this might } \\
\text { have been different. }\end{array}$ \\
\hline 54. & $\begin{array}{l}\text { Slee et } \\
\text { al }\end{array}$ & 2008 & $\begin{array}{l}\text { Clinical } \\
\text { Psycholo } \\
\text { gy \& } \\
\text { Psychot } \\
\text { herapy }\end{array}$ & $\begin{array}{l}\text { Female } \\
(84) \\
\text { Male (6) }\end{array}$ & 90 & Aged 15-35 & $\begin{array}{l}\text { RCT } \\
\text { CBT + } \\
\text { TAU } \\
\text { Vs } \\
\text { TAU }\end{array}$ & $\begin{array}{l}\text { DSH over } 3 \\
\text { months }\end{array}$ & $\begin{array}{l}\text { 1. Mediating } \\
\text { variable that } \\
\text { makes CBT } \\
\text { effective is } \\
\text { unknown. } \\
\text { 2. Unable to } \\
\text { distinguish } \\
\text { between suicide }\end{array}$ & $\begin{array}{l}\text { 1. \& 2. ASK!!! } \\
\text { Are treatment effects due to CBT having an impact on levels } \\
\text { of anxiety and depression? } \\
\text { Authors suggest its due to teaching emotion regulation, } \\
\text { however this has been suggested to be overly emphasized } \\
\text { as a cause of SH }\end{array}$ \\
\hline
\end{tabular}




\begin{tabular}{|c|c|c|c|c|c|c|c|c|c|c|}
\hline & & & & & & & & & and $\mathrm{SH}$ & \\
\hline 55. & $\begin{array}{c}\text { Slee et } \\
\text { al }\end{array}$ & 2008 & $\begin{array}{l}\text { British } \\
\text { Journal } \\
\text { of } \\
\text { Psychiat } \\
\text { ry }\end{array}$ & $\begin{array}{l}\text { Female } \\
(72) \\
\text { Male (5) }\end{array}$ & $\begin{array}{c}77 \\
40 \\
\text { experi } \\
\text { menta } \\
\text { I grp } \\
37 \text { ctrl }\end{array}$ & $\begin{array}{l}\text { All aged } 15-35 \\
\text { referred from } \\
\text { single Dutch site }\end{array}$ & $\begin{array}{l}\text { RCT } \\
\text { TAU + } \\
\text { CBT } \\
\text { Vs } \\
\text { TAU }\end{array}$ & $\begin{array}{l}\text { Repetition of } \\
\text { SH over } 3 \\
\text { months }\end{array}$ & $\begin{array}{l}\text { Assessment of } \mathrm{SH} \\
\text { not a well validated } \\
\text { tool and no } \\
\text { instruments to } \\
\text { assess function } \\
\text { and motive for SH } \\
\text { were available at } \\
\text { the time. }\end{array}$ & SSI exploring SH would serve as a valid tool. \\
\hline 56. & $\begin{array}{l}\text { Spinho } \\
\text { ven et } \\
\text { al. }\end{array}$ & 2009 & $\begin{array}{l}\text { J. of } \\
\text { Nervous } \\
\text { and } \\
\text { mental } \\
\text { disease }\end{array}$ & $\begin{array}{c}93 \% \\
\text { Female }\end{array}$ & 90 & $\begin{array}{l}\text { All aged 15-35 } \\
\text { taken from Slee et } \\
\text { al (2008) }\end{array}$ & $\begin{array}{l}\text { RCT } \\
\text { TAU } \\
\text { Vs } \\
\text { TAU + } \\
\text { CBT }\end{array}$ & Multiple & $\begin{array}{l}\text { Unclear which } \\
\text { aspects of the } \\
\text { experimental } \\
\text { group was useful, } \\
\text { CBT or parts of } \\
\text { TAU }\end{array}$ & ASK! \\
\hline 57. & $\begin{array}{l}\text { Steven } \\
\text { son \& } \\
\text { Meare } \\
\text { s }\end{array}$ & 1992 & $\begin{array}{c}\text { America } \\
\mathrm{n} \mathrm{J.} \mathrm{of} \\
\text { Psychiat } \\
\text { ry }\end{array}$ & $\begin{array}{l}\text { Female } \\
\quad(19) \\
\text { Male (11) }\end{array}$ & 30 & All BPD & $\begin{array}{c}\text { A-B } \\
\text { design }\end{array}$ & $\begin{array}{l}\text { Multiple } \\
\text { including } \\
\text { episodes of } \\
\text { SH, drug } \\
\text { misuse, } \\
\text { hospital } \\
\text { admission } \\
\text { and BPD } \\
\text { symptoms }\end{array}$ & $\begin{array}{c}\text { Again limitations } \\
\text { around why there } \\
\text { was a treatment } \\
\text { effect }\end{array}$ & ASK! \\
\hline 58. & $\begin{array}{l}\text { Steven } \\
\text { son et } \\
\text { al }\end{array}$ & 2005 & $\begin{array}{l}\text { Psycholo } \\
\text { gical } \\
\text { Medicine }\end{array}$ & $\begin{array}{l}\text { Female } \\
\qquad(19) \\
\text { Male (11) }\end{array}$ & 30 & $\begin{array}{l}\text { All BPD and } \\
\text { referred for } \\
\text { psychotherapy }\end{array}$ & $\begin{array}{l}\text { Therapy } \\
\text { Vs } \\
\text { Control of } \\
\text { assessme } \\
\text { nt data }\end{array}$ & $\begin{array}{l}\text { Numerous } \\
\text { including } \\
\text { repetition of } \\
\text { SH }\end{array}$ & & $?$ \\
\hline 59. & $\begin{array}{l}\text { Tyrer } \\
\text { et al }\end{array}$ & 2004 & $\begin{array}{c}\text { J. } \\
\text { Personal } \\
\text { ity } \\
\text { Disorder }\end{array}$ & $\begin{array}{l}\text { No info } \\
\text { see Tyrer } \\
\text { et al } \\
(2003 a)\end{array}$ & $\begin{array}{l}480 \\
239 \\
\text { (MAC } \\
\text { T) } 241\end{array}$ & No info & $\begin{array}{l}\text { Between } \\
\text { groups } \\
\text { MACT Vs } \\
\text { TAU }\end{array}$ & $\begin{array}{l}\text { 1. Anxiety \& } \\
\text { depression } \\
\text { symptoms } \\
\text { 2. Social }\end{array}$ & $\begin{array}{l}\text { Only } 60 \% \\
\text { compliance with } \\
\text { MACT }\end{array}$ & $\begin{array}{l}\text { PAR to explore why such a low compliance? Due to being } \\
\text { given a manual and asked to attend the sessions? Too } \\
\text { impersonal? } \\
\text { No exploration of motives for SH }\end{array}$ \\
\hline
\end{tabular}




\begin{tabular}{|c|c|c|c|c|c|c|c|c|c|c|}
\hline & & & & & $(\mathrm{TAU})$ & & & 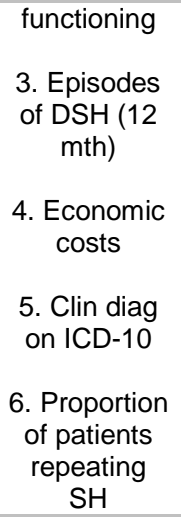 & & $\begin{array}{l}\text { "The results of our study do not give a clear indication of the } \\
\text { place of CBT in the condition" PAR to ask what is/isn't } \\
\text { useful in the CBT approach. }\end{array}$ \\
\hline 60. & $\begin{array}{l}\text { Wallen } \\
\text { stein \& } \\
\text { Nock }\end{array}$ & 2007 & $\begin{array}{l}\text { America } \\
\text { n J. } \\
\text { Psychiat } \\
\text { ry }\end{array}$ & Female & 1 & Single case study & $\begin{array}{c}\text { A-B } \\
\text { design }\end{array}$ & $\begin{array}{l}\text { Self-report } \\
\text { repetition of } \\
\text { SH. }\end{array}$ & None & $\begin{array}{l}\text { As previous it would have been interesting to know in what } \\
\text { ways the woman found exercise useful. Especially given a } \\
\text { reportedly very strong treatment effect. }\end{array}$ \\
\hline 61. & $\begin{array}{l}\text { Walter } \\
\text { s }\end{array}$ & 1983 & $\begin{array}{l}\text { Nursing } \\
\text { Times }\end{array}$ & Female & 1 & $\begin{array}{l}\text { No info on } \\
\text { sampling }\end{array}$ & $\begin{array}{l}\text { Case } \\
\text { study/ethn } \\
\text { ography }\end{array}$ & None & None & $\begin{array}{l}\text { Approach was informed family therapy via nurses, registrar } \\
\text { and social workers. Although aim of intervention was to } \\
\text { improve family communication the patient still seemed to be } \\
\text { a passive recipient of this plan. }\end{array}$ \\
\hline 62. & $\begin{array}{l}\text { Weinb } \\
\text { erg et } \\
\text { al }\end{array}$ & 2006 & $\begin{array}{l}\text { J. } \\
\text { Personal } \\
\text { ity } \\
\text { Disorder }\end{array}$ & Female & 30 & All diagnosed BPD & $\begin{array}{l}\text { Between } \\
\text { groups } \\
\text { design, } \\
\text { random } \\
\text { allocation } \\
\text { to MACT } \\
\text { or TAU }\end{array}$ & $\begin{array}{l}1 . \\
\text { Frequency } \\
\text { of SH } \\
\text { 2. Severity } \\
\text { of SH } \\
\text { 3. Suicide } \\
\text { ideation }\end{array}$ & $\begin{array}{l}\text { Adjunctive } \\
\text { treatment co- } \\
\text { occuring with other } \\
\text { interventions }\end{array}$ & Ask what aspects of treatment the person found most useful. \\
\hline 63. & $\begin{array}{c}\text { Wheatl } \\
\text { ey }\end{array}$ & 2005 & $\begin{array}{l}\text { Behvaio } \\
\text { ural and } \\
\text { Cog } \\
\text { Psychot } \\
\text { herapy }\end{array}$ & Female & 1 & $\begin{array}{l}\text { Single case study. } \\
\text { Medium Secure } \\
\text { Adolescence } \\
\text { service } \\
\text { BPD }\end{array}$ & $\begin{array}{l}\text { A-B case } \\
\text { design }\end{array}$ & $\begin{array}{l}\text { 1. Repetition } \\
\text { of SH. } \\
\begin{array}{l}\text { 2. Use of } \\
\text { coping skills } \\
\text { through self- } \\
\text { report and } \\
\text { staff }\end{array}\end{array}$ & $\begin{array}{l}\text { Revision of } \\
\text { treatment goal } \\
\text { from release to } \\
\text { reduced security } \\
\text { may alleviate } \\
\text { stress }\end{array}$ & $\begin{array}{l}\text { +Coping skills were developed in conjunction with the } \\
\text { participant } \\
\text { Asking the patient why use of coping skills and associated } \\
\text { reduction of SH. }\end{array}$ \\
\hline
\end{tabular}




\begin{tabular}{|c|c|c|c|c|c|c|c|c|c|c|}
\hline & & & & & & & & $\begin{array}{c}\text { corroboratio } \\
n\end{array}$ & & \\
\hline 64. & $\begin{array}{l}\text { Wisem } \\
\text { an }\end{array}$ & 2003 & $\begin{array}{l}\text { Nursing } \\
\text { Times }\end{array}$ & $\begin{array}{l}\text { Not } \\
\text { stated }\end{array}$ & 40 & $\begin{array}{c}\text { All referred to } \\
\text { Psychiatry Liaison } \\
\text { Team. } \\
\text { No previous history } \\
\text { of SH. }\end{array}$ & $\begin{array}{l}\text { A-B } \\
\text { design }\end{array}$ & $\begin{array}{l}\text { Repetition of } \\
\text { SH }\end{array}$ & $\begin{array}{l}\text { Being sent for } \\
\text { therapy may mean } \\
\text { the person isn't } \\
\text { motivated to } \\
\text { engage }\end{array}$ & $\begin{array}{l}\text { Perhaps if the PLT offered a choice of intervention then this } \\
\text { wouldn't be an issue? }\end{array}$ \\
\hline 65. & Zich & 1984 & $\begin{array}{l}\text { Suicide } \\
\text { and Life } \\
\text { Threaten } \\
\text { ing } \\
\text { Behavio } \\
\text { ur }\end{array}$ & Female & 1 & $\begin{array}{l}\text { Case study } 21 \mathrm{yr} \\
\text { old college student }\end{array}$ & $\begin{array}{c}\text { Qualitative } \\
\text { account of } \\
\text { interventio } \\
n\end{array}$ & $\begin{array}{l}1 . \\
\text { Parasuicidal } \\
\text { Beh. } \\
\text { 2. Use of } \\
\text { restraint on } \\
\text { patient }\end{array}$ & $\begin{array}{l}\text { Ward staff were } \\
\text { wary of giving the } \\
\text { patient autonomy }\end{array}$ & $\begin{array}{l}\text { PAR in the sense of collaborative therapeutic relationship. } \\
\text { Patient able to set level of intervention/observation. } \\
\text { Self determined level of intervention were agreed as suitable } \\
\text { by staff } 100 \% \text { of the time. } \\
\text { MH workers as 'listeners' most common form of prevention } \\
\text { requested by the patient. Patient able to select the member } \\
\text { of staff to talk to. } \\
\text { Would more involvement of the staff have overcome the } \\
\text { identified limitation? }\end{array}$ \\
\hline
\end{tabular}

